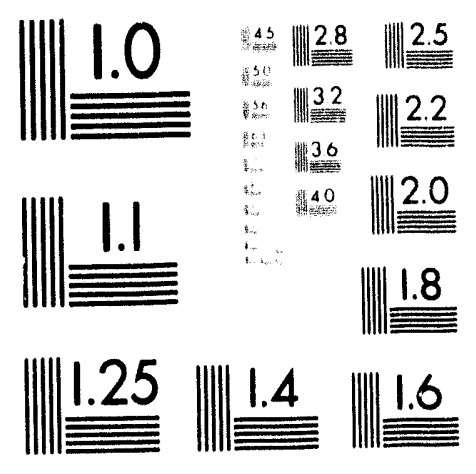



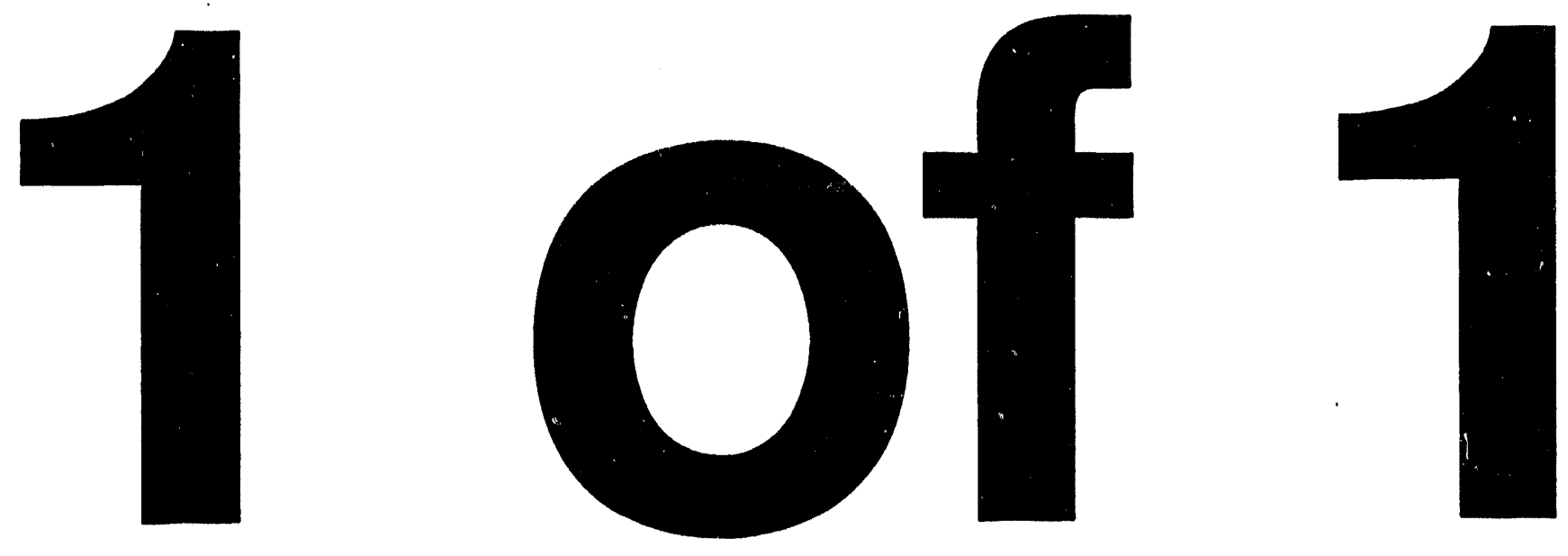


\section{MISCELLANEOUS RADIOACTIVE MATERIALS \\ DETECTED DURING URANIUM \\ MILL TAILINGS SURVEYS}

M. J. Wilson

Date Published: October 1993

Prepared by the

OAK RIDGE NATIONAL LABORATORY

Oak Ridge, Tennessee 37831-6285

managed by

MARTIN MARIETTA ENERGY SYSTEMS, INC.

$$
\text { for the }
$$

U.S. DEPARTMENT OF ENERGY under Contract No. DE-ACO5-84OR21400 


\section{CONTENTS}

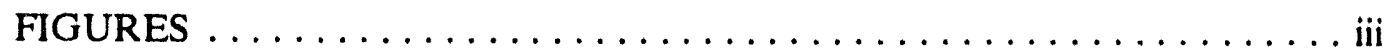

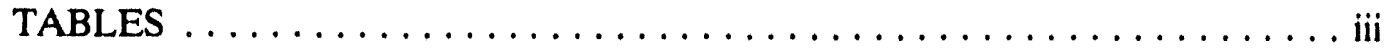

ACKNOWLEDGEMENTS $\ldots \ldots \ldots \ldots \ldots \ldots \ldots \ldots \ldots \ldots$

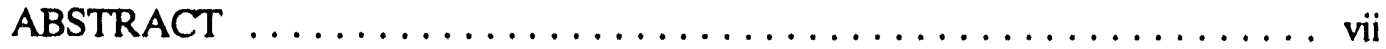

1. INTRODUCTION $\ldots \ldots \ldots \ldots \ldots \ldots \ldots \ldots \ldots \ldots \ldots \ldots \ldots \ldots \ldots$

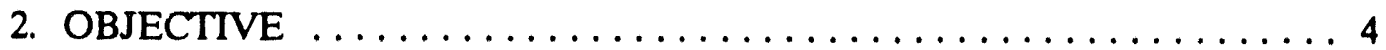

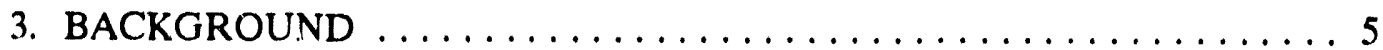

3.1 HISTORY OF RADIOACTIVE MATERIALS $\ldots \ldots \ldots \ldots \ldots 5$

3.2 MILLSITES $\ldots \ldots \ldots \ldots \ldots \ldots \ldots \ldots \ldots \ldots \ldots \ldots, \ldots \ldots \ldots, \ldots \ldots \ldots$

3.3 PREVIOUS SURVEYS $\ldots \ldots \ldots \ldots \ldots \ldots \ldots \ldots \ldots$

3.4 SURVEY PROCEDURE $\ldots \ldots \ldots \ldots \ldots \ldots \ldots \ldots$

3.5 SURVEY RESULTS $\ldots \ldots \ldots \ldots \ldots \ldots \ldots \ldots \ldots \ldots$

4. DRY VALLEY MILLSITE $\ldots \ldots \ldots \ldots \ldots \ldots \ldots \ldots \ldots \ldots \ldots$

4.1 HISTORICAL BACKGROUND $\ldots \ldots \ldots \ldots \ldots \ldots \ldots \ldots$

4.2 PHYSICAL DESCRIPTION $\ldots \ldots \ldots \ldots \ldots \ldots \ldots \ldots \ldots$

4.3 RADIOLOGICAL PROFILE .................. 15

4.4 USE OF DRY VALLEY TAILINGS ON MVP ........... 17

4.5 RADIATION LEVELS ON MVP FROM DRY VALLEY MATERIAL ............................ 19

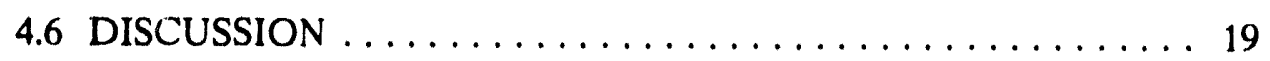

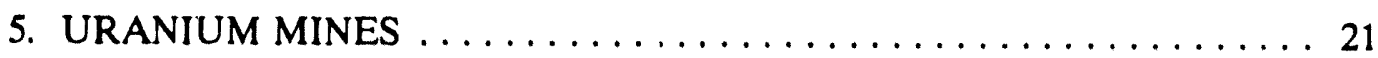

6. COLLECTOR'S ITEMS AND MISCELLANEOUS SOURCES $\ldots \ldots \ldots 22$

7. RADIOACTIVE COAL ........................... 22

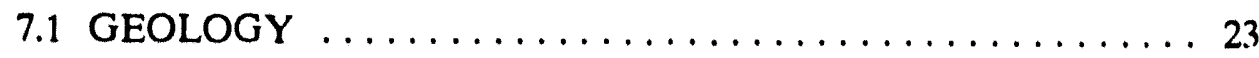

7.2 COAL INVESTIGATION RESULTS $\ldots \ldots \ldots \ldots \ldots \ldots 24$

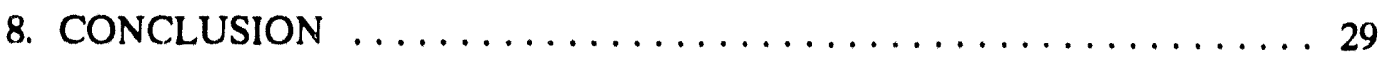


REFERENCES $\ldots \ldots \ldots \ldots \ldots \ldots \ldots \ldots \ldots \ldots \ldots \ldots \ldots \ldots$

ACRONYMS AND INITIALISMS $\ldots \ldots \ldots \ldots \ldots \ldots \ldots \ldots \ldots \ldots \ldots$

APPENDIX A PROPERTIES AFFECTED BY MASONRY

CONTRACTOR, 1975 TO 1989

APPENDIX B DRY VALLEY MILLSITE PROPERTIES

APPENDIX C MISCELLANEOUS AND NATURALLY

OCCURRING RADIOACTIVE MATERIAL

APPENDIX D COLLECTOR'S ITEMS AND OTHER POINT SOURCES

APPENDIX E

COAL SAMPLES 


\section{FIGURES}

1. Monticello, Utah, in San Juan County ................ 2

2. Detail of San Juan County $\ldots \ldots \ldots \ldots \ldots \ldots \ldots \ldots \ldots \ldots \ldots \ldots \ldots \ldots \ldots$

3. Monticello vicinity properties $\ldots \ldots \ldots \ldots \ldots \ldots \ldots \ldots$

4. General location of the Dry Valley millsite $\ldots \ldots \ldots \ldots \ldots \ldots \ldots 12$

5. Detailed location of the Dry Valley millsite $\ldots \ldots \ldots \ldots \ldots \ldots \ldots$

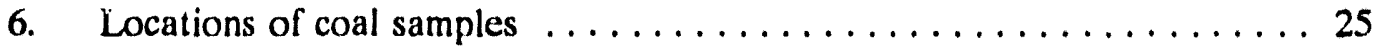

7. Ratio of non-Monticello millsite occurrences $\ldots \ldots \ldots \ldots \ldots \ldots$

\section{TABLES}

1. ${ }^{226} \mathrm{Ra}$ concentrations of material collected at the Dry Valley millsite . . . 16

2. Locations and measurements of coal samples ............. 26

A-1. Properties affected by masonry contractor during 1975 to 1989 . . . . A A-1

B-1. Dry Valley millsite properties $\ldots \ldots \ldots \ldots \ldots \ldots \ldots \ldots \ldots$ B-1

C-1. Miscellaneous and naturally occurring radioactive material . . . . . . C-1

D-1. Collectors' items and other point sources .............. 


\section{ACKNOWLEDGEMENTS}

I wish to acknowledge and thank the technical personnel and management of the Pollutant Assessments Group for their contributions and continuing support of the Monticello activities. In particular, recognition goes to D. B. Ertel and G. K. Stowe for field-team leadership; A. R. Jones, S. M. Fields, and S. K. Mather for technical/field support; D. S. List, M. E. Mumby, D. L. Sellers and S. M. Smith for the coal investigation; G. A. Pierce for radionuclide analysis, N. F. Lewis for computer programming, C. D. Retolaza and E. P. Schlauger for public relations and data base support; J. W. Crutcher and B. J. Krall for technical writing/editing; and D. K. Halford and Craig A. Little for PAG management. D. N. Mackenzie, W. E. Murphie, and D. J. Williamson, in support of the Department of Energy, were valuable sources of direction and encouragement throughout the study. 


\begin{abstract}
The Department of Energy's (DOE) Office of Environmental Restoration and Waste Management directed the Oak Ridge National Laboratory Pollutant Assessments Group in the conduct of radiological surveys on properties in Monticello, Utah, associated with the Monticello millsite National Priority List site.

During these surveys, various radioactive materials were detected that were unrelated to the Monticello millsite. The existence and descriptions of these materials were recorded in survey reports and are condensed in this report. The radioactive materials detected are either naturally occurring radioactive material, such as rock and mineral collections, uranium ore, and radioactive coal or manmade radioactive material consisting of tailings from other millsites, mining equipment, radium dials, mill building scraps, building materials, such as brick and cinderblock, and other miscellaneous sources.

Awareness of the miscellaneous and raturally occurring material is essential to allow DOE to forecast the additional costs and schedule changes associated with remediation activities. Also, material tiat may pose a health hazard to the public should be revealed to other regulatory agencies for consideration.
\end{abstract}




\section{INTRODUCTION}

In 1978, under the authority of the Atomic Energy Act, the U.S. Department of Energy (DOE) estatlished the Surplus Facilities Management Program (SFMP) to manage the maintenance and surveillance of numerous DOE-owned, radioactively contaminated facilities that were declared surplus and to conduc. a program leading to the ultimate disposition of those facilities. The former uranium millsite at Monticello, Utah, is one such facility and is the focus of the Monticello Remedial Action Project (MRAP). Properties surrounding the millsite and contaminated with millsite material are also subject to cleanup under SFMP. These are addressed in the Monticello vicinity properties (MVP) project. The general location of Monticello, Utah, and detail of the Monticello area are shown in Figs. 1 and 2.

The primary responsibility of SFMP, now referred to as the Office of Environmental Restoration and Waste Management (EM), was to protect public health and the environment from potentially harmful radioactive material contained within or derived from DOE-owned facilities. Management of MRAP and MVP is currently directed within EM by the Division of Southwestern Area Programs at DOE Headquarters, Washington, D.C. The Superfund Amendment and Reauthorization Act of 1986 (SARA) placed the SFMP-MVP activities under the regulatory framework of the Comprehensive Environmental Response, Compensation, and Liability Act (CERCLA). The Environmental Protection Agency (EPA), DOE. and the state of Utah entered into a federal facilities agreement (FFA) in December 1988 to complete remedial action at both MRAP and MVP. The FFA details the responsibilities of all parties and the scope of the project. The reader is thus referred to the FFA work plan for a further description of project scope, regulations, and responsibilities (UNC Geotech 1989a).

Prior to the remediation of the Monticello millsite under MRAP, privately owned properties surrounding the millsite were assessed for inclusion in the MVP 


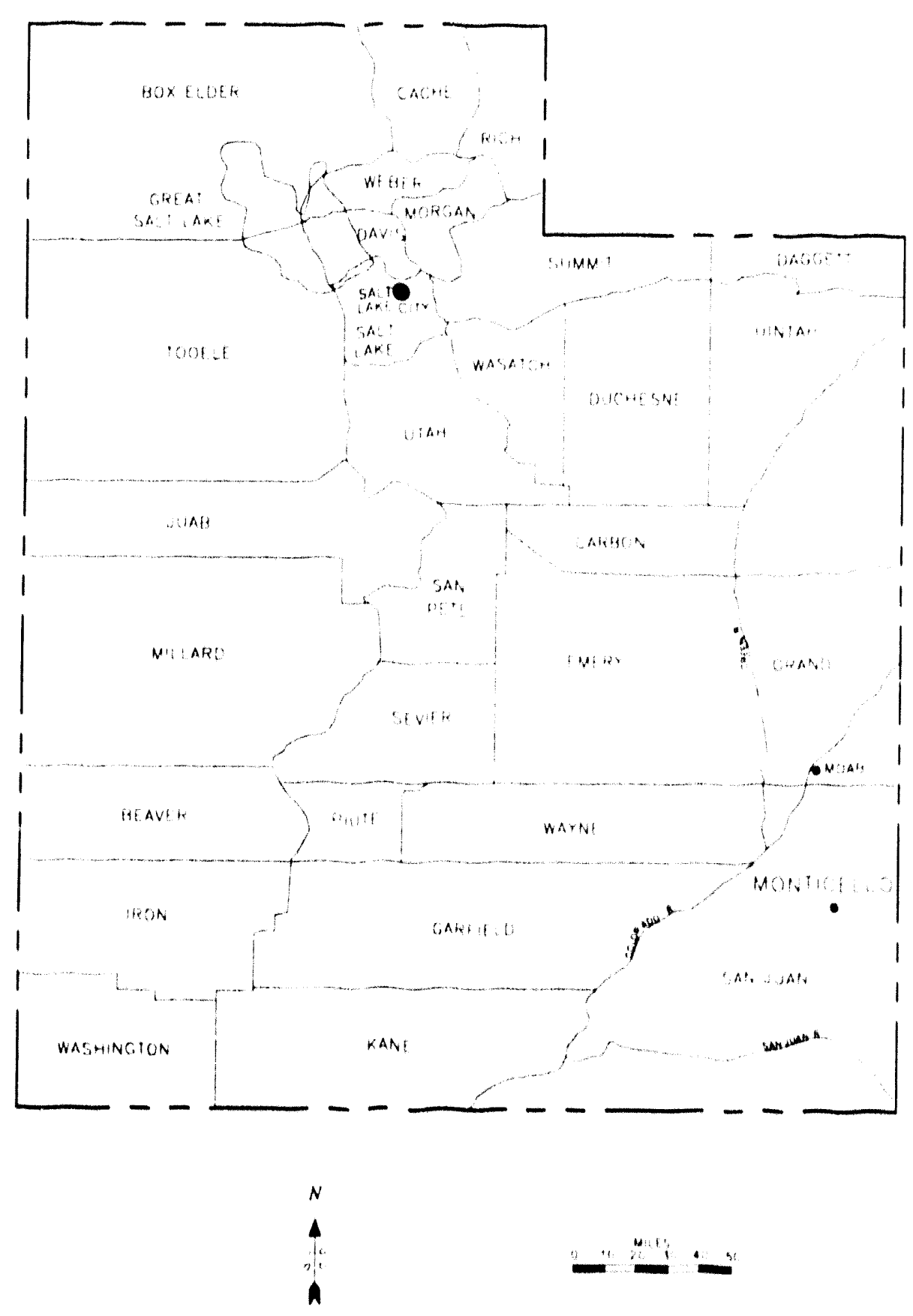

Fig. 1. Monticello, Utah, in San Juan County. 


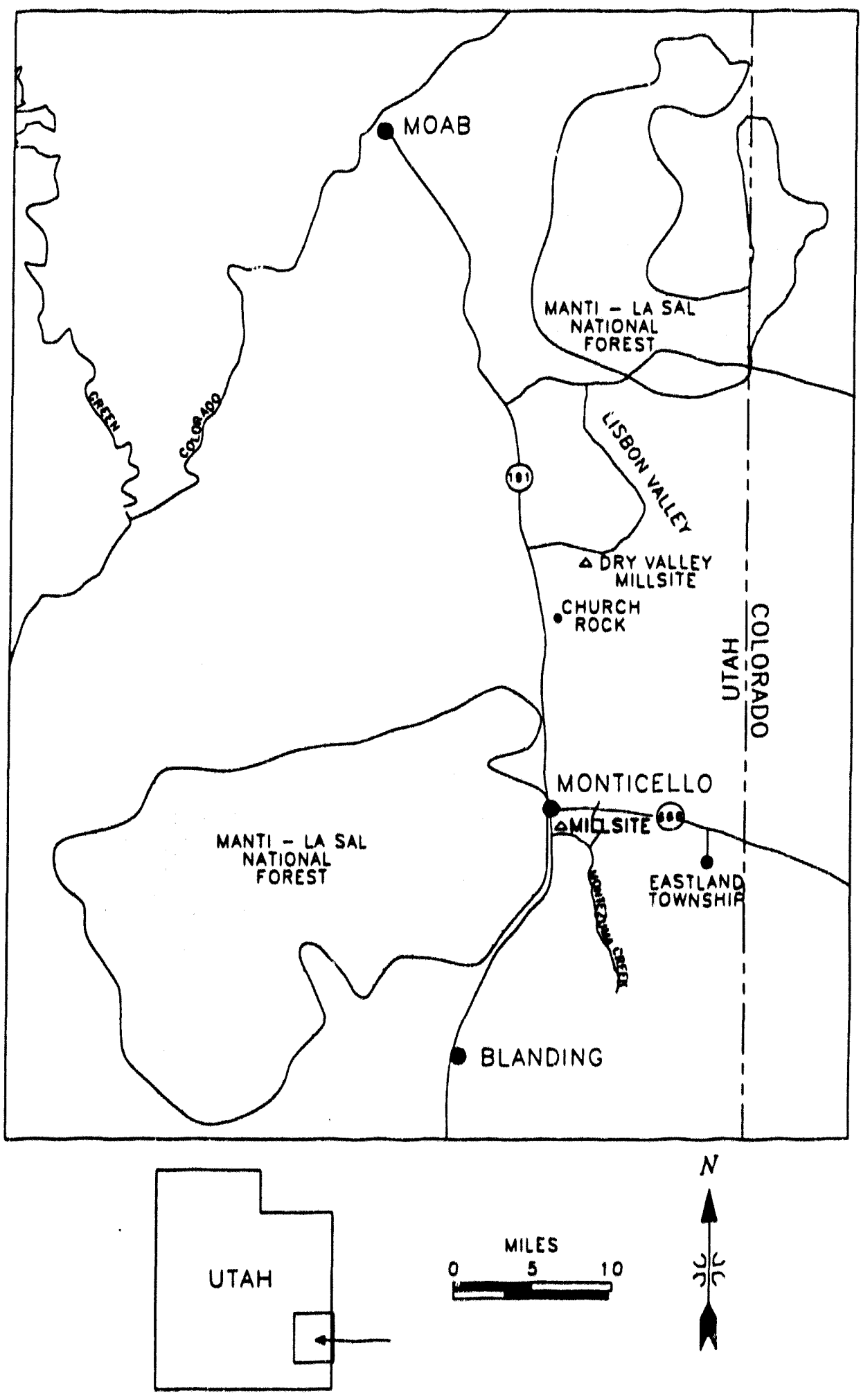

Fig. 2 Detail of San Juan County. 
project. The Pollutant Assessments Group (PAG) of Oak Ridge National Laboratory (ORNL), Grand Junction, Colo. (GJ), was directed by DOE in July 1988 to conduct surveys of the radiological condition of properties potentially contaminated with Monticello mill-related materials. Those with associated radiation levels that exceed DOE guidelines and the EPA standards set forth in 40 CFR 192 are eligible for cleanup under the MVP project (U.S.DOE 1987; U.S.EPA 1991). ORNL/PAG performed 786 gamma radiation screening surveys for mill-related materials.

\section{OBJECTIVE}

The objective of this report is to describe and document the various radioactive materials unrelated to the Monticello millsite that were detected during MVP radiological screening surveys. The existence of these materials was recorded in survey reports throughout the MVP inclusion survey process. The radioactive materials detected during surveys are either naturally occurring or anthropogenic (i.e., caused by man). Naturally occurring radioactive material (NORM) consists of rock and mineral collectors' items, uranium ore, and radioactive coal. Anthropogenic material consists of Dry Valley mill tailings, mining equipment, radium dials, mill building scraps, building materials such as brick and cinderblock, and other miscellaneous sources.

Radioactive materials unrelated to the Monticello millsite may present a possible health risk to the public if used as fill material beneath structures or as masonry constituents. These materials can produce elevated ${ }^{226} \mathrm{Ra}$ concentrations in soil that result in elevated radon progeny. Naturally occurring radioactive materials present in geological formations in the western states may pose the same health. risk potential as mill-related radioactive material if used outdoors or as fill material beneath structures. However, since no known Monticello structure sits directly on any such formations, in situ hazards are not considered here. 
On the other hand, non-Monticello mill-related material can be excavated as if it were residual material from the Monticello millsite. The cost of such clean-ups will be at the expense of DOE, according to an agreement between DOE, EPA. and the state of Utah, even though some of the material may be unrelated to DOE activities at the previously operated Monticello millsite.

\section{BACKGROUND}

\subsection{HISTORY OF RADIOACTIVE MATERIALS}

Commercial mining of uranium-bearing carnotite and tyuyamunite ores began in Colorado and Utah in the early decades of the 1900s. Processing mills were constructed near large mines or an artery of small mines to stockpile, grind, and leach the ore for radium (used as luminous paint and in medical radiography) and vanadium (used for hardening steel). These privately owned mines and mills were operated until the ore source was exhausted, which could have been for a few months or a few years. Once the mines became unprofitable, they were abandoned, as were the mills they supplied.

During World War II, the demand for vanadium increased, and ores that previously would have been unprofitable were mined and processed for their vanadium content. Additionally, the war effort and its defense-related projects for the develnpment of nuclear energy provided an increased demand for uranium and plutonium, a synthetir element produced from uranium. The Army Corps of Engineers' Manhattan Engineer District, established in 1942 to develop nuclear energy, relied on three sources for uranium: 1) the Belgian Congo, which supplied about two-thirds; 2) the Great Bear Lake mines of Canada, which supplied about one-sixth; and 3) the United States, which supplied the remainder. 
Most domestic uranium was supplied by the carnotite ores of the Colorado Plateau. However, the high-grade uranium deposits had been exhausted by the demand for radium. Thus, this domestic supply of uranium consisted primarily of uranium oxide obtained from tailings resulting from vanadium refinery operations (UNC Geotech 1989b).

The radioactive mill tailings that are by-products of the uranium and vanadium milling processes are stored in piles near the mills. If not contained and controlled, these sandy materials can be scattered about the environment by erosion and human intervention. Radiological surveys conducted at the request of DOE have determined that local area residents near a tailings storage site sometimes remove these radioactive materials for use as fill or as aggregate in concrete or mortar. When the origin of these materials can be traced to a governmentowned or formerly government-owned facility, it is the policy of DOE to renove any radioactive material that may be present on privately owned vicinity properties. As a result of radiological surveys conducted as part of the MVP project, properties with radioactive material that resulted from sources other than the governmentowned millsite have been identified. This report will concentrate on the origin and description of these radioactive materials and identify some of the parameters that may be used to determine if the source is the DOE-owned Monticello mill or some other source, such as the Dry Valley millsite or naturally occurring geological formations.

\subsection{MILLSITES}

The mil'site at Monticello, Utah, was built in 1942 by the United States government to provide vanadium during World War II. Various government agencies operated the mill until 1947. In 1948, the Atomic Energy Commission (AEC) obtained the mill and operated it under contract through 1959 for the 
purpose of producing both uranium and vanadium. During the AEC era, the mill

processed approximately one million metric tons of uranium ore. Because uranium and vanadium were the only substances extracted in the milling process, other constituents of the ore such as radium and thorium remained in the tailings at the time of their disposal. Throughout the mill's operation, area residents used these tailings as fill material and as aggregate in mortar and concrete. On January 1, 1960, mill operations were terminated, and in July 1965, the ore stockpiles and other contaminated material were removed from public access and the millsite foundations covered with topsoil. During 1974 and 1975, additional cleanup by DOE included demolition of the concrete foundations and their subsequent trench burial. In 1981, the millsite was declared surplus and accepted into the SFMP; it awaits remedial action to bring its condition up to current DOE standards.

Another millsite in the area is a privately owned, former vanadium mill, the Dry Valley millsite, located approximately $40 \mathrm{~km}$ northeast of Monticello (Fig. 2). This mill produced vanadium from 1931 to 1938. Monticello residents and building contractors used radioactive material from this site extensively. The Dry Valley millsite was covered and revegetated in 1984 .

\subsection{PREVIOUS SURVEYS}

Several radiological investigations and surveys were conducted in Monticello prior to the assignment of ORNL/PAG in July 1988 as the primary survey contractor. In 1971, EPA sponsored a survey that investigated 494 structures in Monticello and recorded 62 radiological anomalies. In 1980, another EPA-sponsored survey examined 810 structures and recorded 55 gamma radiation anomalies (gamma radiation measurements $20 \%$ greater than brckground) (U.S.EPA 1984). These EPA surveys, using mobile gamma detection, were performed at the request of property owners. In 1982, Bendix Field Engineering Corporation surveyed 
the properties identified by the EPA surveys to provide further information on their radiological condition. In 1983, ORNL, Oak Ridge, Tenn., conducted a mobile gamma scan that located 36 additional properties exhibiting anomalous gamma levels (Little and Berven 1985). On-site surveys were conducted at these properties and at the previously identified properties to once again assess radioactive material for inclusion in the remedial action program.

In addition to investigations and surveys conducted by EPA and DOE, other radiological studies were performed in Monticello in the early 1980s. A legal action alleging that seven leukemia deaths in Monticello were the result of ionizing radiation emanating from the Monticello mill tailings piles prompted studies by the University of Utah and others. These studies involved the measurement of cumulative gamma radiation dose from brick and porcelain samples obtained from residences throughout the town (Johnson 1990).

In light of this history, MRAP and the MVP project, in accordance with SARA, were placed under the regulatory framework of CERCLA. Both the MRAP and Monticello millsite MVP have been on the National Priorities List (NPL) since 1987. Because MVP are on the NPL, extra measures to identify potentially contaminated properties were undertaken. In 1989, DOE directed UNC Geotech and ORNL, both in Grand Junction, Colo., to survey all privately owned properties within a six-section area encompassing the city of Monticello and surrounding populated properties. There are approximately 1,000 MVP; these are outlined in Fig. 3.

\subsection{SURVEY PROCEDURE}

Consents to access properties were obtained from landowners, radiological screeming surveys were performed, and soil samples were collected and analyzed for each vicinity property. 


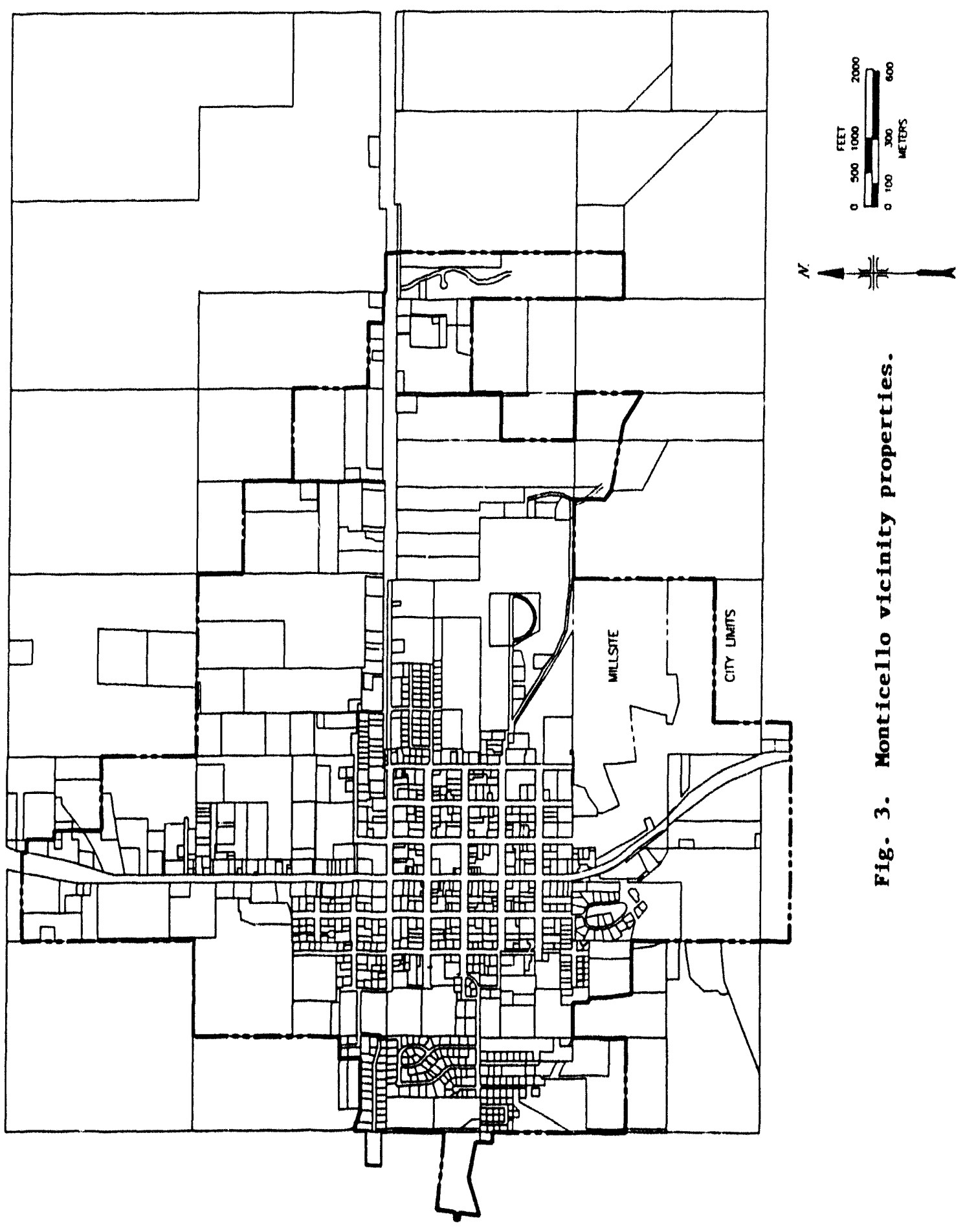


Radiological surveys were in accordance with DOE-approved radiological survey procedures developed by ORNL/PAG for use in the MVP project and also in the Uranium Mill Tailings Remedial Action Project (UMTRAP)(ORNL 1990). These surveys covered each land parcel in its entirety. Radiation exposure rates were recorded and mapped. Soil samples were collected at each property from locations exhibiting elevated gamma levels or from locations exhibiting general background if no elevated gamma exposure rates were detected. The soil samples were then laboratory-analyzed for ${ }^{226} \mathrm{Ra},{ }^{40} \mathrm{~K}$, and ${ }^{232} \mathrm{Th}$ using a Nal gamma spectrometer. It should be noted that background gamma ranges from 11 to $15 \mu \mathrm{R} / \mathrm{h}$ with an average value of $13 \mu \mathrm{R} / \mathrm{h}$ (Little and Berven 1985).

\subsection{SURVEY RESULTS}

ORNL has surveyed 786 MVP since 1988, of which 215 exceeded DOE guidelines, 512 did not exceed, and 59 are currently in the radon daughter concentration (RDC) monitoring process.

Elevated radiation levels that included non-Monticello mill-related radioactive material were noted during surveys. When possible, the existence of non-Monticello mill-related radioactive material was documented in the survey by a statement from the property owner, and these properties were not included for remedial action in the MVP project. However, in some instances documentation of radioactive material origin was not possible, or the radioactive material was a combination of sources related and not related to the Monticello millsite. When these cases were encountered, it was the policy of DOE to take the conservative approach of including these properties for remedial action if they exceeded DOE guidelines. Radioactive materials that did not result from Monticello millsite activities include: 1) radioactive material originating from the Dry Valley millsite, 2) material from various uranium mines, 3 ) ore samples acquired by area residents as "collectors" items", 4) radioactive coal used by residents for heat and for fill matcrial, and 5) other miscellaneous sources. These materials are described in the following pages. 


\section{DRY VALLEY MLLSITE}

\subsection{HISTORICAL BACKGROUND}

Dry Valley, Utah, is the large expanse of land between the La Sal Mountains near Moab, Utah, and the northern end of the Abajo (Blue) Mountains west of Monticello. The Dry Valley millsite is located east of Highway 191, in Lisbon Valley off local Highway 46, approximately $40 \mathrm{~km}$ north of Monticello, in Township 30 South, Range 24 East Sect. 35 (USGS 1987) (Figs. 4 and 5). Most of Sect. 35 is owned by the federal government; however, in the eastern half of the northwest quarter of Sect. 35 are two $0.16-\mathrm{km}^{2}$ parcels of privately owned land. The Dry Valley millsite is located on this privately owned land.

San Juan County Court House records list the International Vanadium Corporation as the earliest owner of these two parcels of land. In 1933, ownership was transferred to the Molybdenum Corporation of America (Moly Corp), the current owner of record. Moly Corp was acquired by Unocal in July 1977 and is operated as a wholly owned subsidiary.

Earlier ownership of the Dry Valley millsite and the exact period of mill operation are uncertain. A local history (Perkins et al. 1968) states that the old United States Vanadium Company built a 20 -ton $\left(1.8 \times 10^{4} \mathrm{~kg}\right)$ mill $35 \mathrm{~km}$ northeast of Monticello in 1924 and the Alloy Corporation built a mill in Dry Valley in 1929. Another source (Minobras 1978) denotes the Dry Valley mill in its Colorado/Utah listing and states that the Dry Valley mill produced vanadium during the years 1931 to 1938. Regardless of the exact period of operation, when the ore supply was exhausted, the millsite was abandoned.

There has been no activity in the area since 1977 when the land was obtained by Moly Corp other than reclamation of the Dry Valley millsite in 1984. In February or March 1984. Unocal was requested by the state of Utah, Bureau of 


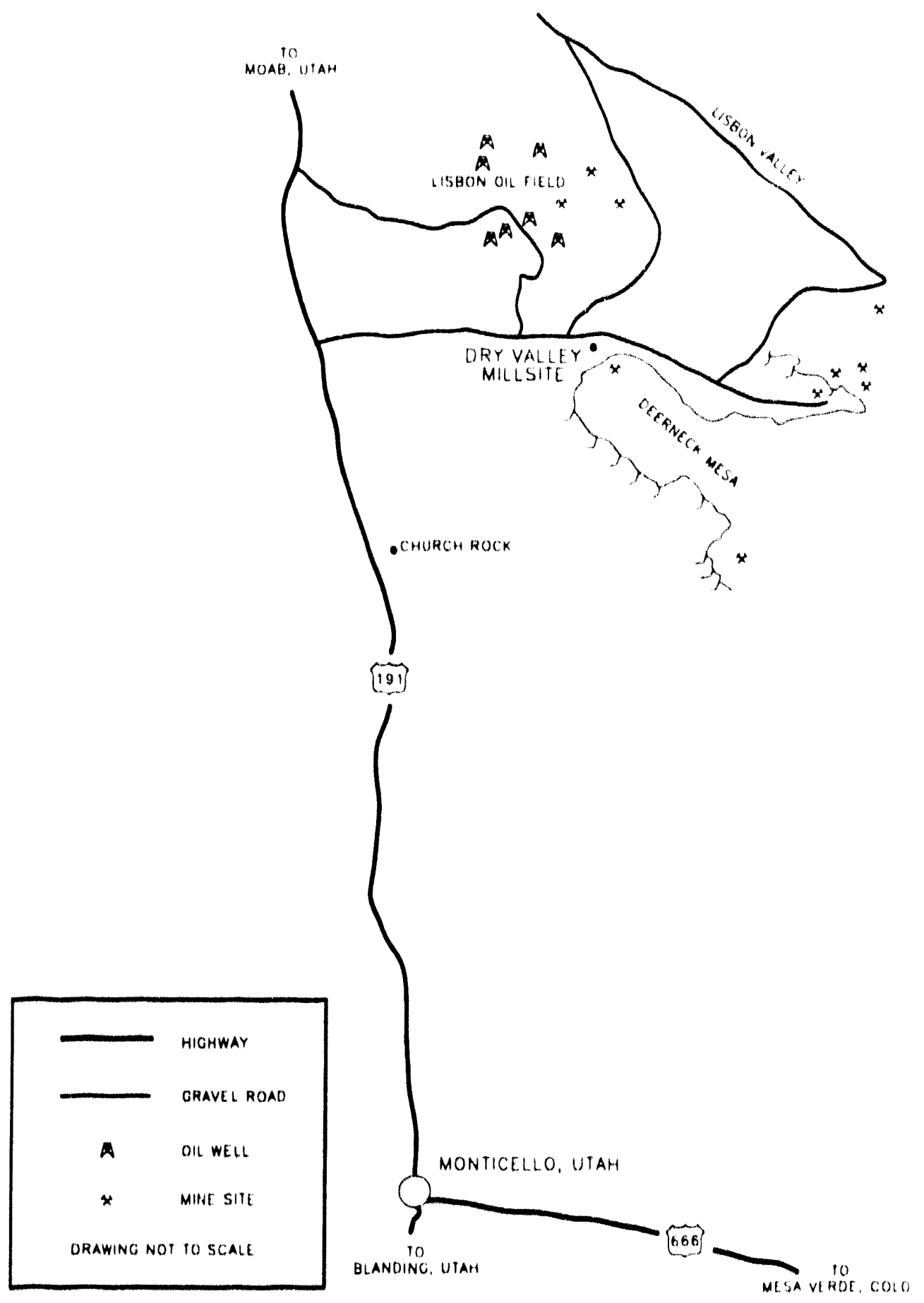

Fig. 4. General location of the Dry Vulley millsite 

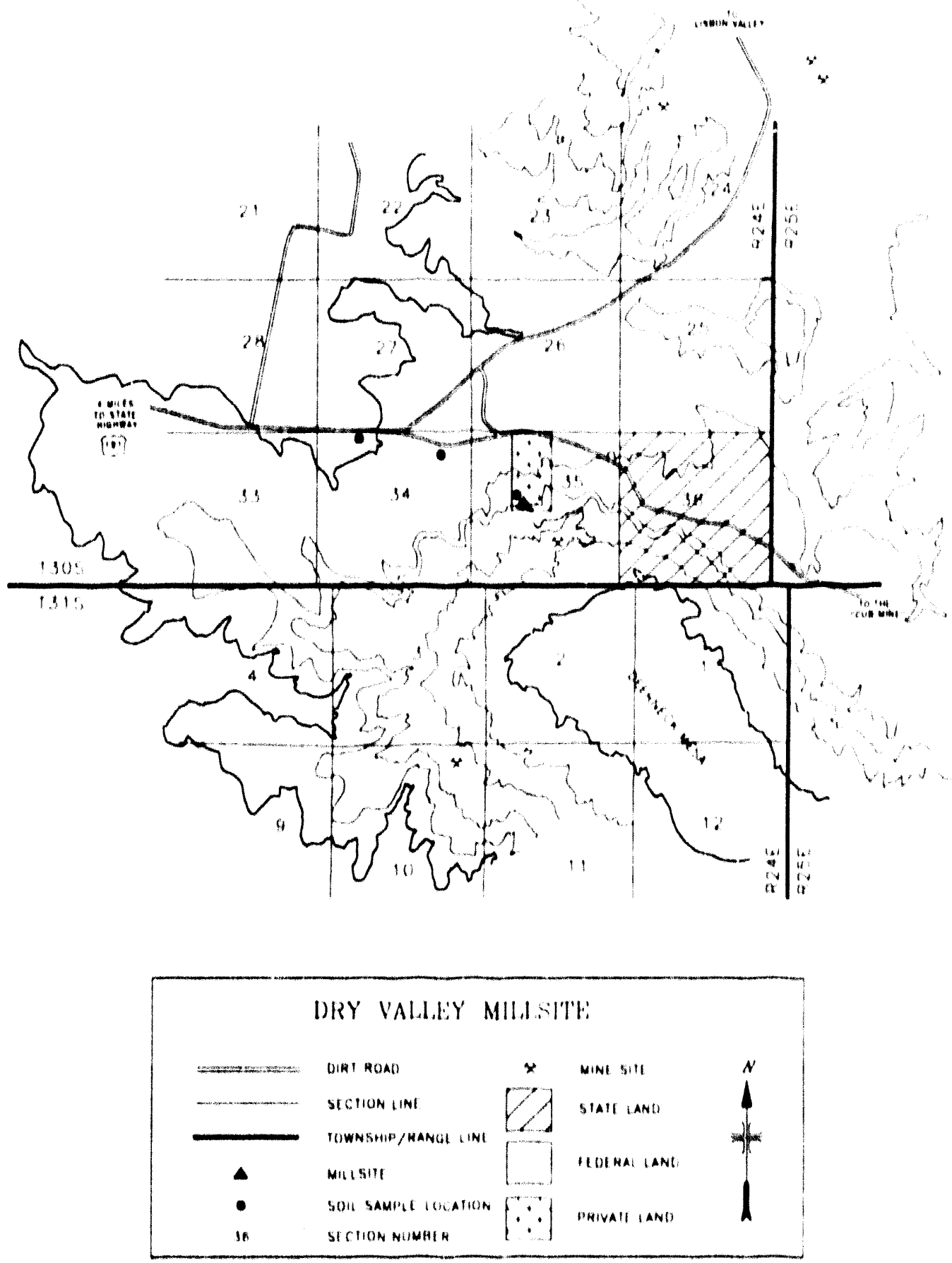

Fig. 5. Detailed location of the Dry Valley millsite. 
Radiation Control, to remove Dry Valley millsite tailings from public access. The state of Utah indicated that up to 100 buildings in Monticello were contaminated from use of Dry Valley tailings material. Unocal and the state of Utah discussed possible options for remediating the site. The options were to: 1) remove the tailings from the millsite, place them in an abandoned mine, and seal the entrance; 2) fence the area; or 3) stabilize and cover the tailings with appropriate matcrial. Unocal studied the options and proposed a reclamation plan that involved grading the tailings, covering with $1 \mathrm{~m}$ of local top soil, and revegetating with local plants (personal communication with G. R. Morris, Union Oil Co., Parachute, Colo., June 1990). The plan was approved by the state of Utah, and reclamation was completed in June/July 1984. The state of Utah indicated aceeptance of the work performed (Anderson 1984).

\subsection{PHYSICAL DESCRIPTION}

Surrounding the Dry Valley millsite is land owned by the U.S. Burellu of Land Management and used primarily for cattle grazing. The old mill sits directly on an outcrop of the Entrada Formation. This outcrop, commonly called the slickrock. forms a hat, sandstone surface below the mill that was apparently used to stockpile ore for mill processing. Remnants of carnotite and other ore remain and can be detected by their yellowish color or by elevated readings on a gamma scintillo. meter.

All that remains of the mill is its concrete foundation, timbers, and a lew scraps of metal and steel reinforcing bar. Ahove the mill, where ore was once stored, are scattered piles of carnotite. Below the mill, stretching out in the general shape of a tongue, is the tailings pile, extending over $91 \mathrm{~m}$. The tailings pile is covered with approximately $1 \mathrm{~m}$ of dirt and sparse vegetation. However, tailings materials are eroding from beneath the cover, and tailings are exposed near the mill. Water erosion has carried tailings toward a wash that runs along the side of and below the road. 


\subsection{RADIOLOGICAL PROFILE}

In June 1990, surface gamma radiation measurements were taken over part of the Dry Valley millsite by ORNL/PAG. Readings were taken with a gamma scintillometer in thousand counts per minute ( $\mathrm{kepm}$ ) and converted to exposure rate $(\mu \mathrm{R} / \mathrm{h})$ using the conversion fuctor derived for the Monticello, Utah, area: $\mu R / h=1.46 \mathrm{kcpm}+7.2$. Scintillometer readings were converted to exposure rates so that gamma measurements at the Dry Valley millsite could be compared to background gamma radiation exposure rates for the Monticello area. As part of the MVP project, Monticello background radiation had been investigated hy ORNL/PAG. The range of gamma radiation exposure rates measured at hack. ground locations in Monticello was $131016 \mu \mathrm{R} / \mathrm{h}$; the average exposure rate was $14 \mu \mathrm{R} / \mathrm{h}$.

Pieces of yellowish uranium ore at the perimeters of the Dry Valley tailings pile have gamma radiation exposure rates on contact of approximately $36 \mu \mathrm{R} / \mathrm{h}$. Exposure rates measured over the dirt cover that shiclds the tailings pile ranged from 29 to $44 \mu \mathrm{R} / \mathrm{h}$. Where tailings had eroded from the cover, measurements roughly doubled, ranging from $661080 \mu R / h$. Emanation from the tailings pile could he detected for a distance of ahout $61 \mathrm{~m}$, and gamma radiation exposure rates increased with proximity to the mill. Exposure rates exceeded 151 \%R/h hoth around the pillars of the millsite and above the mill. Near the ore piles, exposure rates exceeded $3(x) \mu R / h$.

Two soil samples were taken from the mill tailings pile and anulyad for ${ }^{20} \mathrm{Ra}$ concentrations. Results of this analysis revealed ${ }^{22 n} R_{a}$ concentrations of $2(x) \mathrm{pCi} / \mathrm{g}$ and $67 \mathrm{pCi} / \mathrm{g}$. A sample was also collected from the sand wash $46 \mathrm{~m}$ helow the pile. Analysis yielded a ${ }^{20} \mathrm{Ra}$ concentration of $6 \mathrm{pCi} / \mathrm{g}$. Since background level for the area is $2 \mathrm{pCi} / \mathrm{g}$ (Rust Geotech 199.3), this may indicate that water has eroded material from the pile and dispersed it throughout the wash helow. Table 1 lists

${ }^{226}$ Ra concentrations for samples taken from the Dry Valley millsite and vicinity. 
Table 1. DRa concentrations of material collectod at the Lry Valley millate

\begin{tabular}{|c|c|c|c|}
\hline $\begin{array}{l}\text { Sample } \\
\text { number }\end{array}$ & $\begin{array}{l}2{ }^{2 x} \mathrm{Ra} \text { Concentration, } \\
\mathrm{pCl} / \mathrm{g}\end{array}$ & $\begin{array}{l}\text { Sample } \\
\text { Depth, cm }\end{array}$ & Location \\
\hline S1 & 302 & 0 to 15 & $\begin{array}{l}\text { While sand near former loading } \\
\text { area }\end{array}$ \\
\hline S2 & 94 & 01015 & $\begin{array}{l}\text { White sand on small bench } \\
\text { above millaite }\end{array}$ \\
\hline S.3 & 5.7 & 01015 & $46 \mathrm{~m}$ below pile in wash \\
\hline S4A & 8.2 & 01015 & $\begin{array}{l}-0.8 \mathrm{~km} \text { west of pile along dirt } \\
\text { road }\end{array}$ \\
\hline S4B & 7.2 & 151030 & $\begin{array}{l}-0.8 \mathrm{~km} \text { west of pile along dirt } \\
\text { road }\end{array}$ \\
\hline Ss & 8.8 & & \\
\hline S6 & 1.4 & 01015 & $\begin{array}{l}-1.6 \mathrm{~km} \text { west of pile along dirt } \\
\text { rond }\end{array}$ \\
\hline
\end{tabular}


Despite these elevated radiation measurements, the Dry Valley millsite was readily accessible to the public as late as June 1990). No radioactive warning signs were posted. The mill site and adjoining tailings pile were not lenced. There was no warning or boundary to deter the local populace from driving up to the mill tailings site and taking sand for use in masonry on concrete structures or as fill in yards, driveways, and children's sandhoxes.

Gamma measurements taken over parts of the Dry Valley millsite were all above the background level of 13 to $16 \mu \mathrm{R} / \mathrm{h}$ for the Monticello area. Because the Dry Valley millsite is privately owned and was never used in support of government activities, it is not subject to the DOE guidelines for residual radionctive material at the Formerly Utilized Sites Remedial Action Program (FUSRAP) and SFMP sites (U.S.DOE 1987). Guidelines for control of tailings piles and cleanup of huildings and land are found in 40 CFR Part 192 (U.S. EPA 19.1). For control of tailing piles, these guidelines are based on radon emissions from the surface of tailings pile (no more than $20 \mathrm{pCl} / \mathrm{m}^{2}$ ). For buildings, the guidelines are hased on: (1) radon (an annual average not to exceed 0.02 working levels [WL. and a maximum limit of $0.03 \mathrm{WL}$ ) and (2) gamma exposure rates (a maximum measurement

of $20 \mu \mathrm{R} / \mathrm{h}$ ). For land, the guidelines are based on concentrations of ${ }^{20} \mathrm{Ra}$ in soil: a maximum of $5 \mathrm{pCi} / \mathrm{g}$ in surface soil, 0 to $15 \mathrm{~cm}(0)$ to $6 \mathrm{in}$.) decp and $15 \mathrm{pCi} / \mathrm{g}$ in subsurface soil, $>15 \mathrm{~cm}$ ( $>6$ in.) deep. Since the Dry Valley millsite was a vana. dium mill before the Manhatlan Project era. the 40 CFR 192 standards may not apply because they address by-products of uranium millsites.

\subsection{USE OF DRY VALLEY TAILINOS ON MVP}

In October 1989, DOE directed ORNL to research the use of Dry Valley millsite material by local Monticello building contractors. Property owners whose huildings were found to have elevated gamma radiation rates were questioned 
during radiological surveys about the possible origin of construction materials. The owners consistently reported that the structures in question were built by one specific local masonry contractor. The structures were usually brickwork, such as brick siding, fireplaces, chimneys, and occasionally rock masonry. The primary contractor reported to have used the material was contacted and interviewed during June 1990. ORNL was supplied with verbal confirmation of the following points:

- The masonry contractor's company was formed in 1973, after the Monticello millsite tailings pile was stabilized. Matcrial from the Monticello millsite was never used in the contractor's projects.

- The sand used by the masonry contractor in mortar for brick masonry came from all over southeastern Utah, and was not limited to one source. Sand was hauled from the Dry Valley millsite in addition to dry washes in the Lishon Valley and Church Rock areas. Sr.nd was also purchased in Cortez, Colo., and in Dolores, Colo. The sand from these distributors came from various sources, including Shiprock, New Mexico, and Mexican Hat, Utah.

- The musonry contractor provided a written statement that Monticello millsite matcrial was never used in his construction projects. The contractor compiled a list of locations of masonry structures (Appendix A). When the list was received. it was checked against surveys of properties containing radioactive brick masonry structures (personal communication with Bunker Construction, June 1990). Approximately $35 \%$ of the properties on the contractor's list were also properties where surveys had detected radioactive masonry. Thus, it was determined that the material found on the surveys was not from the Monticello millsite but was probably from the Dry Valley millsite (Appendix A and B). 
In addition to the Dry Valley tailings used by contractors, several property owners reported using Dry Valley tailings for brick nıortar, concrete matrix, sandboxes, and fill.

\subsection{RADIATION LEVELS ON MVP FROM DRY VALLEY MATERIAL}

The outdoor gamma radiation exposure ranges on properties containing Dry Valley mill tailings vary from a low of 17 to a high of $80 \mu \mathrm{R} / \mathrm{h}$. Indoor exposure ranges vary from a low of $16 \mu \mathrm{R} / \mathrm{h}$ to a high of $92 \mu \mathrm{R} / \mathrm{h}$. Radon progeny have been measured inside homes with masonry structures (brick siding and/or fireplace brick) containing mortar made from Dry Valley tailings material. Appendix $B$ is a compilation of all MVP suspected of containing Dry Valley material. Radon pro. geny measurements and indoor gamma radiation measurements for the properties measured to date are presented in Appendix B.

\subsection{DISCUSSION}

By January 1992, approximately 30 out of 786 MVP had been identified as potentially containing Dry Valley mill-related materials. Ten of these 30 properties were found to exceed DOE/EPA standards (U.S.DOE 1987; U.S.EPA 1991); the state of Utah and EPA were notified.

Property-owner statements concerning the origin of building materials have been used to differentiate Monticello mill-related materials from Dry Valley millrelated materials. Additionally, if a structure is known to have been built after 1963, when the Monticello millsite was fenced and stabilized, any radioactive material in the structure is likely to be from a non-Monticello mill source, presumably Dry Valley. Finally, if the property resides on the list provided by the primary contractor mentioned previously, the radioactive material is presumably not related to the Monticello millsite. 
The research and study of the Dry Valley millsite and associated tailings provide several points for consideration:

- Dry Valley millsite tailings were, and perhaps still are, readily available to the public before approximately 1984.

- In addition to Dry Valley mill materials, severa! inactive uranium mines in the Monticello area provide sources of radioactive sand that is readily available to the public. This makes it difficult to determine if all radioactive material not related to the Monticello millsite is of Dry Valley millsite origin.

- Material from both the Dry Valley millsite and other sites was used extensively in the Monticello area by both contractors and residents.

- ${ }^{226} \mathrm{Ra}$ concentrations in Dry Valley mill tailings materials exceed EPA standards; however, indoor radon progeny measurements, both historical EPA measurements and current ORNL measurements, indicate that many of the structures are constructed in such a way that radon levels fall below EPA standards. Therefore, remedial action may not be necessary on many of the properties in question.

- Material from the Monticello millsite was inaccessible to the public after 1963; therefore, it is not likely that structures built after this time contain material from the Monticello millsite.

- The EPA radiological standards used in the MVP project are those set forth for uranium mill tailings. Since the Dry Valley tailings are vanadium tailings, and pre-Manhattan Engineering District era, they may not be subject to UMTRA standards and could be considered NORM. 
Moly Corp currently is suggesting that the Dry Valley vanadium tailings be disposed of in the nearby Small Fry mine (Associated Press 1993). The mine offers a unique solution for a number of reasons. First, the vanadium waste is less radioactive than rock in the mine's walls, so there is no increase in the level of radiation. Second, the mine is above the water table so there is little risk of groundwater contamination. Finally, the waste would be permanently isolated from the public since the mine will be sealed at the end of the project. The project is currently under review by the state of Utah Division of Radiation Control.

\section{URANIUM MINES}

During examination of the Dry Valley millsite, it was noted that several inactive uranium mines exist in the Lisbon Valley area, within two miles of the Dry Valley millsite (Figs. 4 and 5). Each mine contains tailings and rubble readily accessible to the public. The existence of these readily accessible mines serves to illustrate that the Dry Valley millsite is not the only source of radioactive sand that does not come from the Monticello millsite. An example is Monticello property MS00620 where the property owner brought in mine tailings from the Lisbon Valley area to use for mortar in a flagstone patio. Appendices $C$ and $D$ list several properties containing radioactive uranium mine material.

Uranium mines occur throughout Colorado and Utah; several are in the vicinity of Monticello. Many past and present Monticello residents were in the uranium mining business. Therefore, the occurrence of uranium mining equipment and material should come as no surprise.

Uranium generally is mined in the Morrison Formation, which out-crops throughout the western states. The Chinle and Shinarump Formations also contain uraniumbearing strata and are mined in the area (Stokes 1986). Radioactive material from mines is considered a NORM along with material from sources such as mineral processing, coal ash, phosphate waste, fertilizers, oil and gas wastes, water treatment, and geothermal energy wastes. 


\section{COLLECTOR'S ITEMS AND MISCELLANEOUS SOURCES}

Several residents of the Monticello area have rock collections that include radioactive samples of ores such as carnotite, urananite, tyuyamunite, uranothorite, autnite, torbernite. Most of these ores are derived from the deposits of the region. Petrified wood and bone are also abundant in the region and are used for decorative purposes in masonry, garden borders, and rock gardens. Petrified wood and bone becomes radioactive when uranium-rich solution reacts in a reducing environment and uranium replaces the carbon found in these materials. The source formation is usually the Morrison or Chinle for these samples. Again, residents in the area have historically been in the uranium mining business and often possess highgrade samples from various mines. Collectors' items detected during property surveys are listed and described in Appendix D.

Miscellaneous radioactive material found during surveys not related to the Monticello millsite include radium dials, pumice used for decorative purposes, bricks, and cinderblocks. Miscellaneous sources are also listed and described in Appendix D.

\section{RADIOACTIVE COAL}

Among the sources of radioactive material detected that were unrelated to the Monticello millsite was a radioactive coal-like material that had been used as fill or burned in coal-burning stoves and the ashes disposed of on the property. Because this material exhibits elevated gamma radiation exposure rates, it can potentially exceed DOE guidelines and be subjected to remedial action under the MVP project. 
ORNL investigated sources of radioactive coal for two reasons: 1) to avoid the excavation of naturally occurring radioactive material at the expense of DOE during remedial action of MVP, and 2) to irform DOE of potential health risks to the public from material other than that originating at the Monticello millsite.

The methods used to investigate sources of radioactive coal in the Monticello area included: 1) interviewing experts in geological research pertaining to radioactive coal and the Dakota Formation, 2) pertornine a literature search of coal use and production in the project area, and 3) interviewing property owners concerning the sources of coal-like material on their properties.

\subsection{GEOLOGY}

Field research revealed radioactive coal seams derived from the Dakota Formation, which outcrops frequently in the general region of Monticello. This coal may have been used as fill material by property owners or as fucl for coalburnings stoves throughout the history of the town.

Monticello is located on the Colorado Plateau in southeastern Utah, adjacent to the Abajo Mountains. In this province of the Colorado Plateau, the term Dakota Group is used to refer to all predominantly non-marine deposits of lower Cretaceous age. The Dakota Group consists primarily of buff to light-gray sandstone, with interbedded light- to dark-gray sandstone, carbonaceous shales, and a few thin beds of coal. In the Monticello area and much of southeastern Utah, the Dakota Group is divisible into three distinctive units. The lower unit is a cliff. forming, coarse-grained, conglomeratic sandstone. This sandstone rests unconformably on the underlying Burro Canyon Formation. Distinction hetween the two is sometimes difficult, but can be accomplished with methods not discussed in this report. The middle unit consists of carbonaceous shales, siltstones, and thin coal 
beds with a few interbedded sandstone stringers. This middle unit represents a regressive phase of the Cretaceous seaway. The third and uppermost unit of the Dakota Group is a fine-grained, well-sorted, clean quartz sandstone with low-angle course stratification typical of beach deposits.

The middle unit of the Dakota Group contains the carbonaceous shale and coal that are of interest to this investigation. In the town of Monticello, the Dakota has either been eroded away or buried by pediment gravel. However, just outside of Monticello, the Dakota Group outcrops, containing coal seams 5 to $25 \mathrm{~cm}$ deep of high enough quality to mine (UGMS 1972). In the early 1900s, the townspeople discovered this source and began mining it. Six locations where coal deposits out-crop in the area of Monticello were sampled (Fig. 6). These deposits are all within $80 \mathrm{~km}$ of the town and are easily accessible. It is from these deposits that gamma radiation levels above background and elevated ${ }^{20} R$ a concentrations are typically found. The results of the samples are given in Table 2.

\section{COAL INVESTIGATION RESULTS}

Coal samples taken from MVP were from regions of elevated gamma radiation rates or, if no elevated gamma was recorded, from background regions. Properties containing radioactive coal or coaly shale are included in Appendix $\mathrm{C}$. According to local areas residents, coal brought into Monticello was usually purchased locally from the Price, Utah, area. Residents sometimes obtained "free" coal from the Eastland area (Fig. 6) or western Colorado. Samples found to contain coal were taken from MVP. These samples generally contained a mixture of coal or coal ash and soil. The physical characteristics of the coal found in MVP samples differed from coal originating in the Dakota Folmation. Some coal separated from the MVP samples was vitreous, black, blocky' and subbituminous, with some wood content, while coal from the outcrops near Monticello was shaly, earthy, friable, and lignitic. 


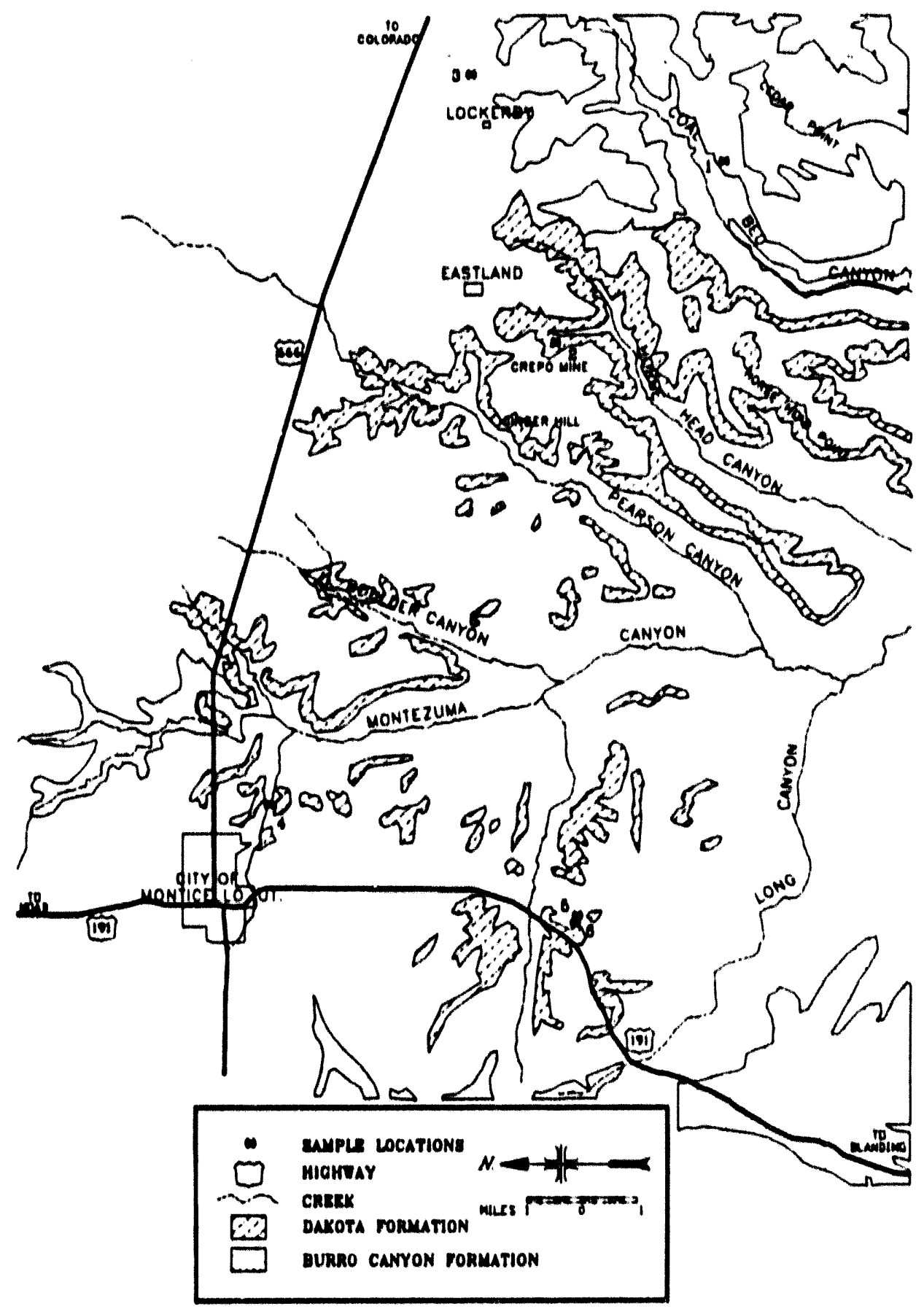

Fig. 6. Locations of coal samples. 
Table 2 Locations and measurements of coal samples

Lucation 1. Coal Bed Canyon, R25E T34S Sect. 17. The Dakota Formation, which is usually distinguished by the change in carbonaceous material, was relatively undifferentiated at this location. Bacisground gamma exposure rates in the sandstone measured $12.31 \mu \mathrm{R} / \mathrm{h}$. The sample was collected from lignite, grading to carbonaceous shale. Exposure rates in the lignite measured from 25 to $29 \mu \mathrm{R} / \mathrm{h}$. A second sample of black friable carbonaceous shale was taken at this location, approximately $1.5 \mathrm{~m}$ below the conglomerate-coal contact. The exposure rate measured $25 \mu R / h$ at this second sample depth. Samples collected here revealed ${ }^{20} \mathrm{Ra}$ concentrations of $2.68 \mathrm{pCi} / \mathrm{g}$ and $2.93 \mathrm{pCi} / \mathrm{g}$.

Location 2 Crepo Mine site. T3SS R25E Sect. 35. Exposure measurements at the old mine site ranged from 17 to $19 \mu \mathrm{R} / \mathrm{h}$ ( $19 \mu \mathrm{R} / \mathrm{h}$ inside the mine and $17 \mu \mathrm{R} / \mathrm{h}$ on top of the stockpiled coal). Crepo Mine supposedly began operation about 1929. which is about the time many of the vicinity properties in Monticello were esta. blished. Sampies collected here revealed ${ }^{26} \mathrm{Ra}$ concentrations of $2.14 \mathrm{pCi} / \mathrm{g}$ and $1.48 \mathrm{pCi} / \mathrm{g}$

Location 3. Road, T35S R24E Sect. 28. This sample was laken in a road cut that appeared to he right above the Morrison Formation and Burro Canyon. Exposure rates measured $22 \mu \mathrm{R} / \mathrm{h}$ at the sample location, dropping to $16 \mu \mathrm{R} / \mathrm{h}$ just above the sampling location where the dark-gray lignitic shale grades 10 lighter-gray silty shale. These layers interbed, with exposure rate measurements ranging from 2010 $25 \mu \mathrm{R} / \mathrm{h}$ in the darker coal. Samples collected here revealed ${ }^{22 h} \mathrm{Ra}$ concentrations of $3.16 \mathrm{pCi} / \mathrm{g}$ and $1.11 \mathrm{pCi} / \mathrm{g}$. 
Table 2 (continuod)

Location 4. This shale sample was taken off Cemetery Road, just below Dakiota Formation top sand. Shale was gray to black, very carbonaceous, with ore grading to shaly lignite. The exposure rate measured $25 \mu \mathrm{R} / \mathrm{h}$ on contact. Samples collected here revealed ${ }^{2 x} \mathrm{Ra}$ concentrations of $3.42 \mathrm{pCi} / \mathrm{g}$.

Location 5. Approximately $1.2 \mathrm{~km}$ from Recapture Creek, this sample was taken in carbonaceous shalc, dark gray 10 hlack, grading (o) shaly lignile. Exposure rates measured $28 \mu \mathrm{R} / \mathrm{h}$ on the surfuce and $39 \mu \mathrm{R} / \mathrm{h}$ at a depth of $15 \mathrm{~cm}$. The second sample taken at this location was approximutely $(x) \mathrm{cm}$ below the first. The sample was taken in coal and pediment gravels, with possible sulphur along the fractures and bedding planes. The exposure rate measured $25 \mu \mathrm{R} / \mathrm{h}$ hoth on the surface and at a $15 \mathrm{~cm}$ depth. A third samiple was taken on the north side of Highway 91 . across the road from the previous two, and was nearly identical to the second sample described ahove. The three samples collected here revealed ${ }^{20} \mathrm{R}$ a concentrations of $6.36 \mathrm{pCi} / \mathrm{g} .3 .47 \mathrm{pCi} / \mathrm{g}$ and $8.87 \mathrm{pCi} / \mathrm{g}$ respectively.

Location 6. Approximately $2 \mathrm{~m}$ stratigraphically above the third sample taken from Lxation 5, this sample was taken in dark gray to black shale, very carbonaceous, grading to lignite, grading down to coul. The sample collected here revealed a ${ }^{20} \mathrm{Ra}$ concentration of $6.4 \mathrm{pCi} / \mathrm{g}$. 
Two samples were $100 \%$ coal and were known to have come from the vicinity Price, Utah, according to the property owner. These samples showed $<1 \mathrm{pCi} / \mathrm{g}$ of ${ }^{20}$ Ra concentration. Coal from the Price area is part of the Mesa Verde Forma. tion and exhibits low radioactivity. This coal is subbituminous, and its physical properties match the coal separated from some of the MVP soil samples. Other coal samples were from coal purchased at the local feed store that reportedly came from the Cortez area.

It can be concluded that samples of Dakota Formation coal and carbonaceous shale from the Monticello area exhibit above-background gamma radiation levels and ${ }^{2 a} \mathrm{Ra}$ concentrations. Background gamma radiation exposure rates range from 13 to $17 \mu R / h$ in the Monticello area, and the average background ${ }^{2 *} \mathrm{Ra}$ concen. tration in soil is $2 \mathrm{pCi} / \mathrm{g}$. Although the coal collected on MVP had no physical characteristics in common with the coul from outcrops, the potential remains for finding coal from the outcrops during excavation.

Since coal from the Dakota Formation was probably used as fuel, coal ash may have been scattered or coal stock-piled on some the properties. A potential for above-background levels of gamma radiation exists if a continuous layer of coal-like material, a large stockpile of coal-like material, or cosal ash is encoun. lered.

If a continuous layer or stockpile of coul with elevated gamma radiation is found on a property during an inclusion survey or remedial action verification, samples should be taken and analyzed. If the ${ }^{226} \mathrm{Ra}$ concentration is above $5 \mathrm{pCi} / \mathrm{s}$. an analysis should be performed to determine if uranium and radium are in equilibrium. A uranium-radium equilibrium indicates that the sample is a naturally occurring source rather than mill tailings, which exhibit a uranium-radium ratio of less than 1. 


\section{CONCLUSION}

Figure 7 displays the occurrences of non.Monticello millsite radionactive materials detected during property surveys. Decorative rock used for landscaping was the largest occurrence, followed by uranium ore samples. Vanadium tailings from the Dry Vulley millsite composed the third most frequent cecurrence.

Remedial action activilien will continue in Monticello through the year 1997. when the site is scheduled to be removed from the NPL. Encounters with natural. ly occurring radioactive material and other radioactive sources not related to the Monticello millsite will continue to occur. Awareness of these materials is essen. lial in allow DOE to forecast the additional costs and schedule changes associated with the discussion of remediating them. Also, material that may pose a health threat to the public should be revealed to other regulatory agencies for consider. ation. 


\section{Chart values represent occaurrences and not individual properties.}

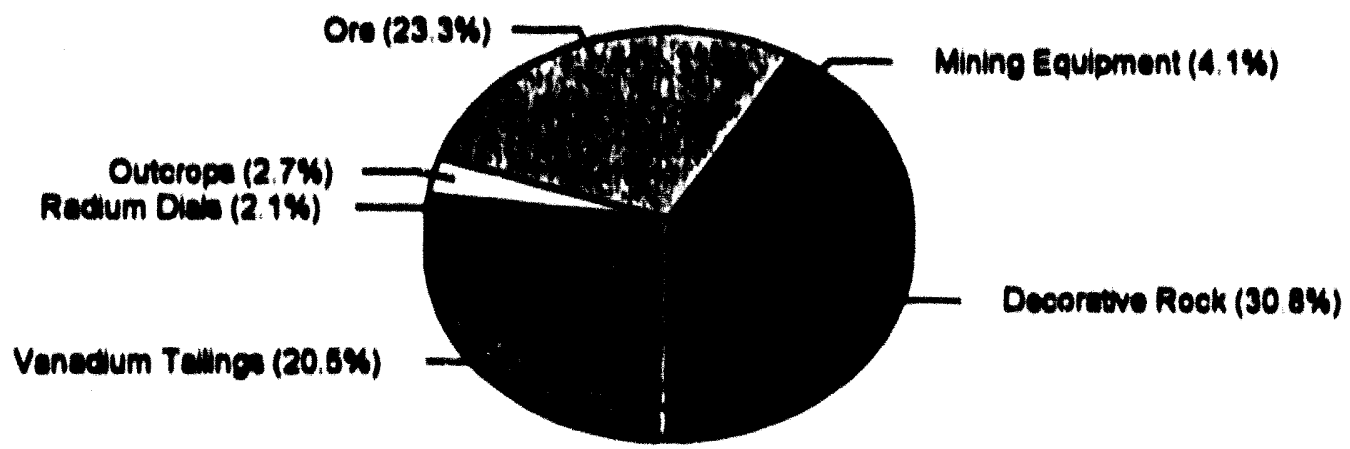

Fig. 7. Non-Monticello-millbile cecurrences. 


\section{REFERENCES}

Anderaon, L. F. 1944. Memorandum to G. Morris, Union Oil Company, Parachute, Colo., August 16. State of Utah Department of Health.

Aarciated Press. 1993. Or Mines and Men: Old Uranium Mine 10 Take Low. Level Rudiouctive Watc. Rocky Mountain Pay Din, January 199.

Johnson. R. H. 19\%). Resolution of the Monticello Uranium Mill Tailings Legal Action. In Environmental Radiation and Public Policy Topical Symposium Proceedings, Lake Meade Chupter of the Health Physics Socicly. Las Vegus, Nev.

Litile. C. A., and B. A. Berven. 1985. Results of the Sunvey Activities and Mobile Gamma Scanning in Monticello, Uiah. ORNLTM.9738. Oak Ridge National Laboratory, Oak Ridge, Tenn.

Minobras. 1978. Uranium Guidebcok for the Paradox Basin. Utah-Colorado. Minobrax, Dana Point, Calif.

ORNL. 19X). Pollutant Assessments Group Procedures Manual. ORNL.(k445. Oak Ridge National Laboratory, Grand Junction. Colo.

Perkins, C. A., M. G. Neilson, and L. B. Jones. 1968. Saga of San Juan. San Juan County Daughters of Ulah Pioneers.

Rust Geotech. 1993. Field Assessments Procedures Manual. Revision 08. Rust Geotech, Grand Junction. Colo. 
Stokes, W. L. 1986. Geoloy of Uiah. Utah Museum of Natural History. University of Utah and Utah Oeological and Mineral Survey, Salt Lake City, Utah.

UOMS. 1972. Utah Oeological and Mineralogical Survey, Monograph Series No. 2., Salt Lake City, Utah.

UNC Oeotech. 1989a. Monticello Uiah, Federal Facilities Agreement Work Plan. UNC Geotech, Orand Junction, Colo.

UNC Geotech. 1989b. Remedial Investigation for the Monticello Uranium Mill Tailings Site, Monticello, Uiah. Revised draft. DOE/ID/12584-21. UNC/GJ-MRAP.2. UNC Geotech, Grand Junction, Colo.

U.S.DOE. 1987. Cuidelines for Residual Radioactive Marerial at Fomerly Uiilized Sites Remedial Action Program (FUSRAP). Revision 2. U. S. Department of Energy. Washington, D.C.

U.S.EPA. 1984. EPA Survey of Possible Mill Tailings Contamination in Monticello, Utah. U. S. Environmental Protection Agency, Region VIIl, Denver, Colo.

U.S.EPA. 1991. Standards for Remedial Actions at Inactive Uranium Processing Sites; Final Rule (40 CFR Part 192). Federal Register, 48:49:447.

USOS, 1987. Sandstone Draw, Utah. 7.5-minute series topographic map Provisional Edition. U. S. Geological Survey, Reston, Va. 


\section{ACRONYMS AND INITIALISMS}

$\begin{array}{ll}\text { AEC } & \begin{array}{l}\text { Atomic Energy Commission } \\ \text { CERCLA }\end{array} \\ \text { DOE } & \begin{array}{l}\text { Comprehensive Environmental Response, } \\ \text { Department of Energy } \\ \text { EM }\end{array} \\ \text { Omice of Environmental Restoration and Waste } \\ \text { Management } \\ \text { Environmental Protection Agency } \\ \text { FFA } & \text { federal facilities agreement } \\ \text { FUSRAP } & \text { Formerly Utilized Sites Remedial Action Program } \\ \text { GJ } & \text { Grand Junction } \\ \text { MRAP } & \text { Monticello Remedial Action Project } \\ \text { MVP } & \text { Monticello vicinity properties } \\ \text { NORM } & \text { naturally occurring radioactive material } \\ \text { NPL } & \text { National Priorities List } \\ \text { ORNL } & \text { Oak Ridge National Laboratory } \\ \text { PAG } & \text { Pollutant Assessments Group } \\ \text { RDC } & \text { radon daughter concentration } \\ \text { SARA } & \text { Superfund Amendment and Reauthorization Act } \\ \text { SFMP } & \text { Surplus Facilities Management Program } \\ \text { UNC } & \text { United Nuclear Corporation } \\ \text { UMTRAP } & \text { Uranium Mill Tailings Remedial Action Project } \\ \text { WL } & \text { working level }\end{array}$


APPENDIX A

PROPERTIES AFFECTED BY MASONRY CONTRACTOR, 1975 TO 1989 
Table A-1. Properties affected by masonry contractor, 1975 to 1989

\begin{tabular}{|c|c|c|}
\hline Location No. & Year of Construction & Type of Construction \\
\hline MSO0002 & 1978 & Veneer \\
\hline MSOOOO2 & 1985 & Veneer/garage \\
\hline MS00004 & 1980 & Fireplace/stove \\
\hline MS00006 & 1978 & Fireplace \\
\hline MS00006 & 1979 & Fireplace \\
\hline MS00006 & 1980 & Veneer \\
\hline MSO0007 & 1976 & Veneer/fireplace \\
\hline MSO0009 & 1979 & Veneer/fireplace \\
\hline MS00016 & 1980 & Brickwork/windows \\
\hline MS00036 & 1974 & Slump block building \\
\hline MS00036 & 1977 & Block \\
\hline MS00037 & 1981 & Slump block \\
\hline MS00037 & 1981 & Slump block \\
\hline MS00055 & 1973 & Rockwork \\
\hline MS00057 & 1979 & Veneer/apartments \\
\hline MS00057 & 1980 & Park plaza veneer \\
\hline MS00059 & 1984 & Block/plaster \\
\hline MS00099 & 1979 & Fireplace \\
\hline MSO0100 & 1976 & Block addition \\
\hline MSO0111 & 1975 & Block wall \\
\hline MS00115 & 1979 & Brick/stucco \\
\hline MSO0118 & 1980 & Brick veneer \\
\hline MS00119 & 1979 & Veneer \\
\hline MSO0120 & 1977 & Veneer \\
\hline MS00121 & 1979 & Veneer \\
\hline MSO0124 & 1989 & Fireplace face \\
\hline MS00125 & 1979 & Rockwork/wall \\
\hline MSO0144 & 1976 & Chimney/fireplace \\
\hline
\end{tabular}


A-2

Table A-1. (continued)

Location No.

Year of Construction

Type of Construction

MS00166

1983

Chimney

MS00169

1980

Veneer

MS00169

1980

Block chimney

MS00169

1985

Veneer

MS00175

1980

Chimney

MS00199

1989

Brick fireplace

MSO0205

1984

Chimney/fireplace

MSO0218

1975

Block vault

MS00218

1975

MS00261

1981

MS00261

1983

MS00265

1989

MS00266

1982

MS00268

1989

MS00268

1975

MS00275

1980

MS00276

1975

MS00284

1976

MS00295

1983

Slump block

Rock/planter

Block veneer

MS00307

1981

MS00307

1983

MSO0323

1979

MS00359

1974

MS00371

1975

MS00387

1985

MS00406

1974

MS00419

1980

MS00425

1985

MSO0426

1981

MS00426

1989

Foundation repair

Veneer/chimney

Repair retaining wall

Rockwork on pavement

Veneer/chimney

Brick veneer

Fireplace

Fill in door

Chimney

Block foundation

Veneer

Block foundations

Veneer/of'tịce

Brick wall/stove

Fireplace

Firewall/block

Veneer/firestation

Fill in window

Veneer storage building 
A-3

Table A-1. (continued)

\begin{tabular}{|c|c|c|}
\hline Location No. & Year of Construction & Type of Construction \\
\hline MSOOA33 & 1981 & Block repair/apartment \\
\hline $\mathrm{MSOO} 433$ & 1981 & Block repair/apartment \\
\hline MSO0455 & 1982 & Block/store \\
\hline MSO0455 & 1984 & Block foundation \\
\hline MSO0461 & 1976 & Veneer \\
\hline MSO0471 & 1973 & Fireplace \\
\hline MSO0475 & 1975 & Fireplace \\
\hline MSO0475 & 1977 & Fireplace \\
\hline MSOO482 & 1975 & Chimney \\
\hline MS00482 & 1979 & Firplace/chimney \\
\hline MSOO486 & 1973 & Brick veneer \\
\hline MSO0499 & 1980 & Chimney/fireplace \\
\hline MSO0514 & 1974 & Fill in window \\
\hline MSO0546 & 1973 & Fireplace/chimney \\
\hline MSO0572 & 1980 & Veneer/chimney \\
\hline MSO0584 & 1973 & Brick fireplace \\
\hline MS00587 & 1974 & Block building \\
\hline MSO0590 & 1973 & Brick veneer \\
\hline MS00601 & 1980 & Wainscot/carport \\
\hline MS00607 & 1982 & Veneer/porch \\
\hline MSO0609 & 1976 & Vencer \\
\hline MSO0617 & 1983 & Fireplace face \\
\hline MS00621 & 1980 & Fireplace \\
\hline MS00628 & 1975 & Chimney/extension \\
\hline MS00632 & 1974 & Veneer/chimney/fireplace \\
\hline MS00632 & 1984 & Veneer/addition \\
\hline MS00633 & 1988 & Fireplace face \\
\hline MSO0633 & 1983 & Vencer/chimney/fireplace \\
\hline
\end{tabular}


A-4

Table A-1. (continued)

\begin{tabular}{|c|c|c|}
\hline Location No. & Year of Construction & Type of Construction \\
\hline MSO0634 & 1976 & Veneer \\
\hline MSO0634 & 1979 & Veneer \\
\hline MSO06:35 & 1989 & Block foundation \\
\hline MSO0635 & 1978 & Fireplace \\
\hline MSO0637 & 1979 & Chimney \\
\hline MSO0643 & 1989 & Brick/stove \\
\hline MSO0644 & 1980 & Chimney \\
\hline MSO0644 & 1980 & Chimney \\
\hline MSO0645 & 1979 & Veneer \\
\hline MSO0645 & 1979 & Veneer \\
\hline MSO0646 & 1982 & Chimney \\
\hline MS00670 & 1974 & Veneer/fireplace \\
\hline MSO0672 & 1974 & Brick veneer \\
\hline MSO0750 & 1977 & Fireplace \\
\hline MS00754 & 1985 & Block walls \\
\hline MS00754 & 1989 & Block/front doors \\
\hline MS00756 & 1989 & Plaster remodel \\
\hline MS00756 & 1981 & Veneer/boiler building \\
\hline MS00756 & 1976 & Doors/blockwork \\
\hline MS00757 & 1974 & Fireplace/rock \\
\hline MSO0805 & 1978 & Fireplace/chimney \\
\hline MSO0810 & 1975 & Brick veneer \\
\hline MSO0826 & 1985 & Block walls \\
\hline MSO0826 & 1988 & Block wall \\
\hline MSO0830 & 1978 & Fireplace/chimney \\
\hline MSO0850 & 1977 & Fireplace \\
\hline MSO0852 & 1980 & Decorative wall \\
\hline MSO0852 & 1977 & Veneer \\
\hline MS00856 & 1974 & Brick veneer \\
\hline MSO0859 & 1976 & Veneer/chimney, \\
\hline
\end{tabular}


A.5

Table A-1. (continuod)

\begin{tabular}{|c|c|c|}
\hline Location No. & Year of Construction & Type of Comsinuction \\
\hline & & Fireplace/retaining wall \\
\hline MS00889 & 1983 & Veneer \\
\hline MS00936 & 1985 & Block foundation \\
\hline MS00945 & 1976 & Veneer/fireplace \\
\hline MS00948 & 1975 & Rock/block/lire \\
\hline MS00950 & 1974 & Fireplace \\
\hline MS00973 & 1985 & Block in doorway \\
\hline MS01058 & 1989 & Fireplace face \\
\hline -Eastland & $19 / 3$ & Rockwork/planter \\
\hline \multirow[t]{21}{*}{ Properties } & 1974 & Block work \\
\hline & 1974 & Brick veneer \\
\hline & 1974 & Chimney/fireplace \\
\hline & 1975 & Brick veneer \\
\hline & 1976 & Veneer \\
\hline & 1978 & Veneer \\
\hline & 1978 & Veneer \\
\hline & 1978 & Veneer \\
\hline & 1978 & Veneer \\
\hline & 1978 & Veneer \\
\hline & 1978 & Block \\
\hline & 1978 & Veneer \\
\hline & 1978 & Veneer/wall \\
\hline & 1978 & Veneer \\
\hline & 1979 & Block \\
\hline & 1979 & Veneer \\
\hline & 1980 & Stove \\
\hline & 1980 & Veneer \\
\hline & 1980 & Block chimney \\
\hline & 1980 & Chimney \\
\hline & 1980 & Brick entry \\
\hline
\end{tabular}


A.6

Table A-1. (continued)

\begin{tabular}{cll} 
Location No. & Yenr of Conetruction & Trpe of Conatruction \\
\hline 1980 & Lamp posts \\
1980 & Block chimney \\
1980 & Remodel \\
1981 & Pillars/planter \\
1981 & Fireplace/chimney \\
1981 & Veneer \\
1973 & Fireplace \\
1983 & Block walls \\
1984 & Chimney/fireplace \\
1984 & Chimney/Blanding \\
1984 & Chimney/Blanding \\
1985 & Veneer/chimney \\
1985 & Veneer/chimney \\
1985 & Block stairwell \\
1985 & Block chimney \\
1985 & Block \\
1989 & Rock on garage \\
1989 & Veneer storage building
\end{tabular}

- Eastland is a small community located approximately $13 \mathrm{~km}$ southeast of Monticello and is outside the MVP project boundary. 


\section{APPENDIX B}

DRY VALLEY MILLSTTE PROPERTIES 


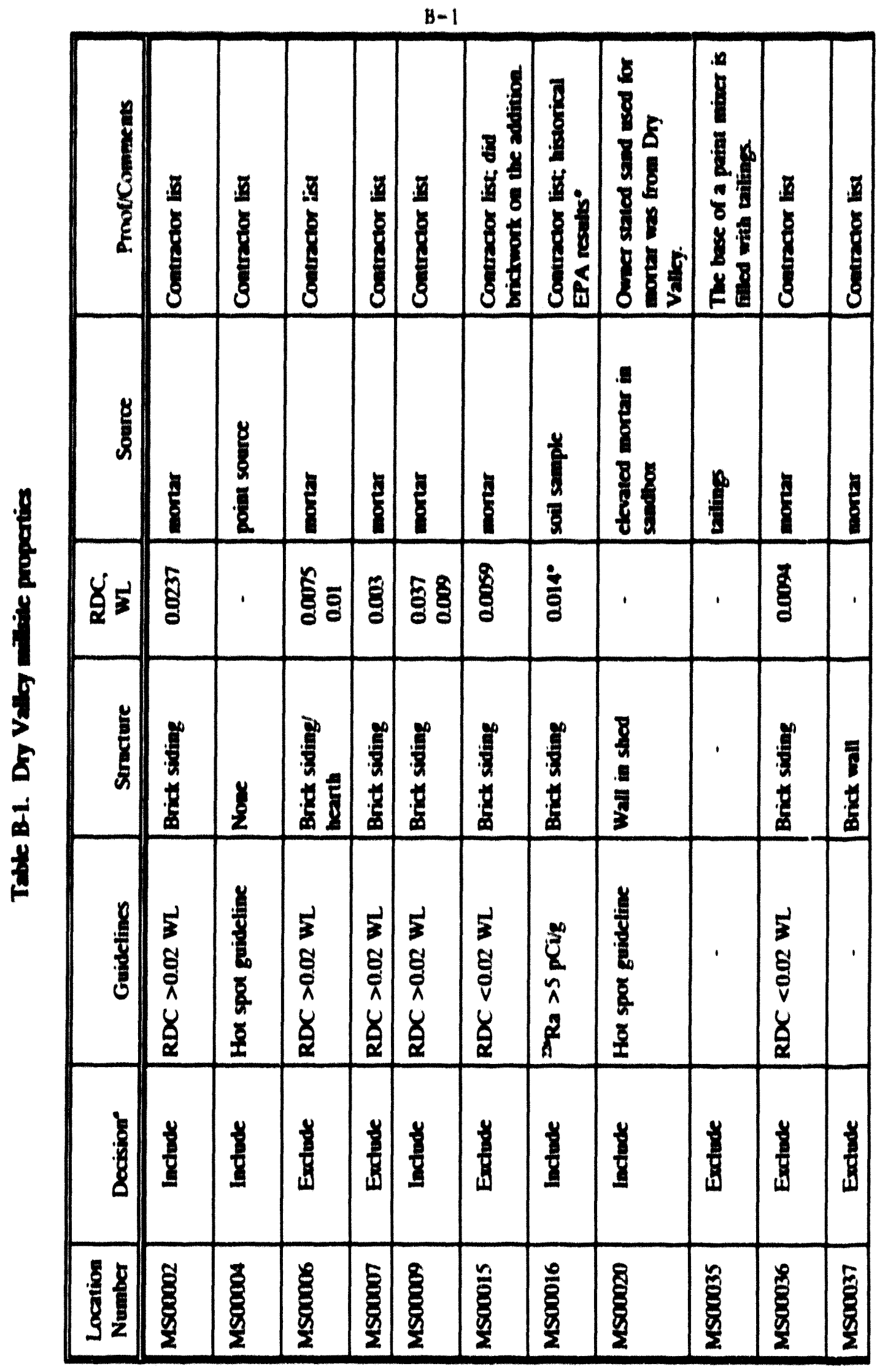


$B-2$

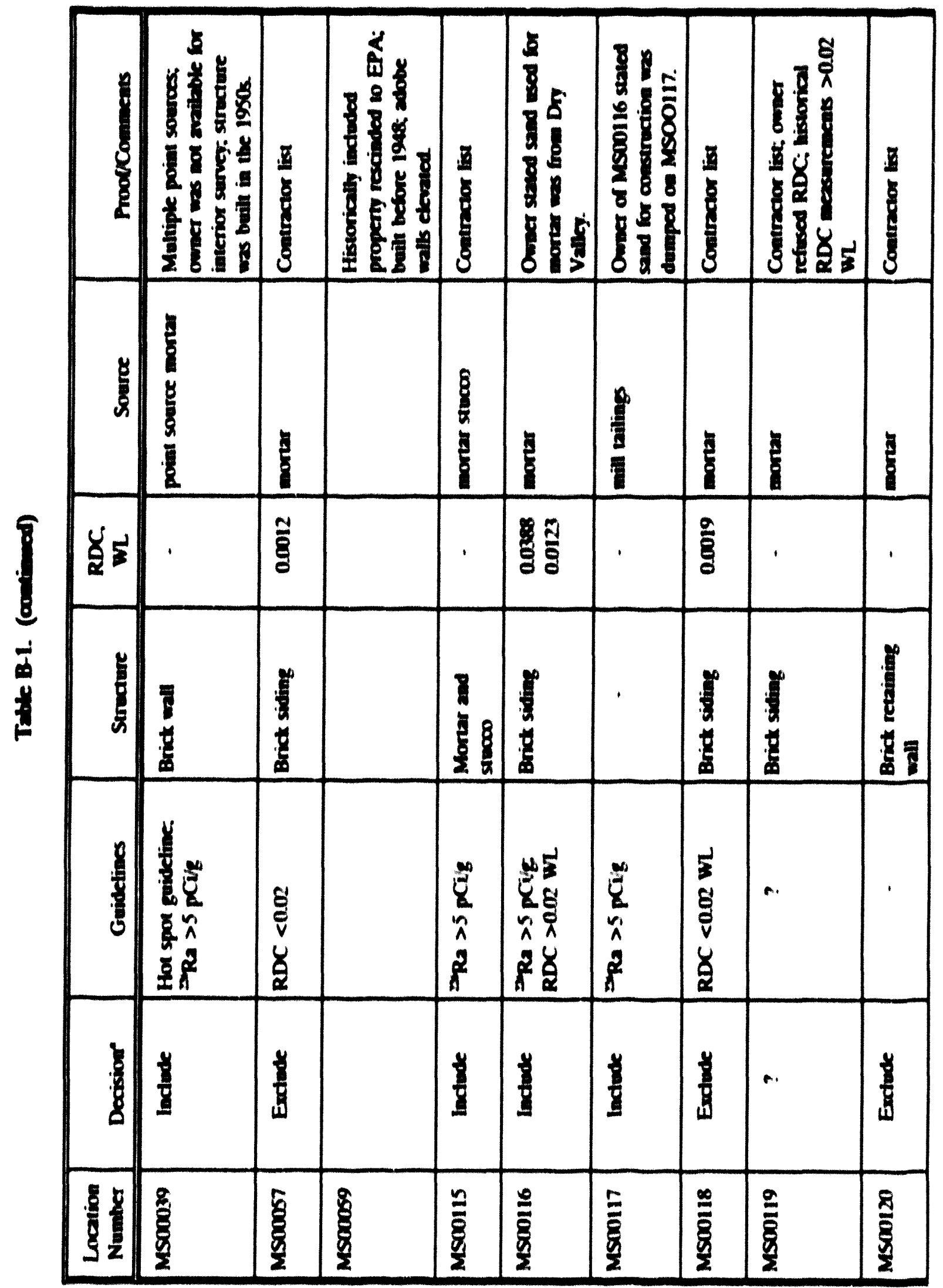


B-3

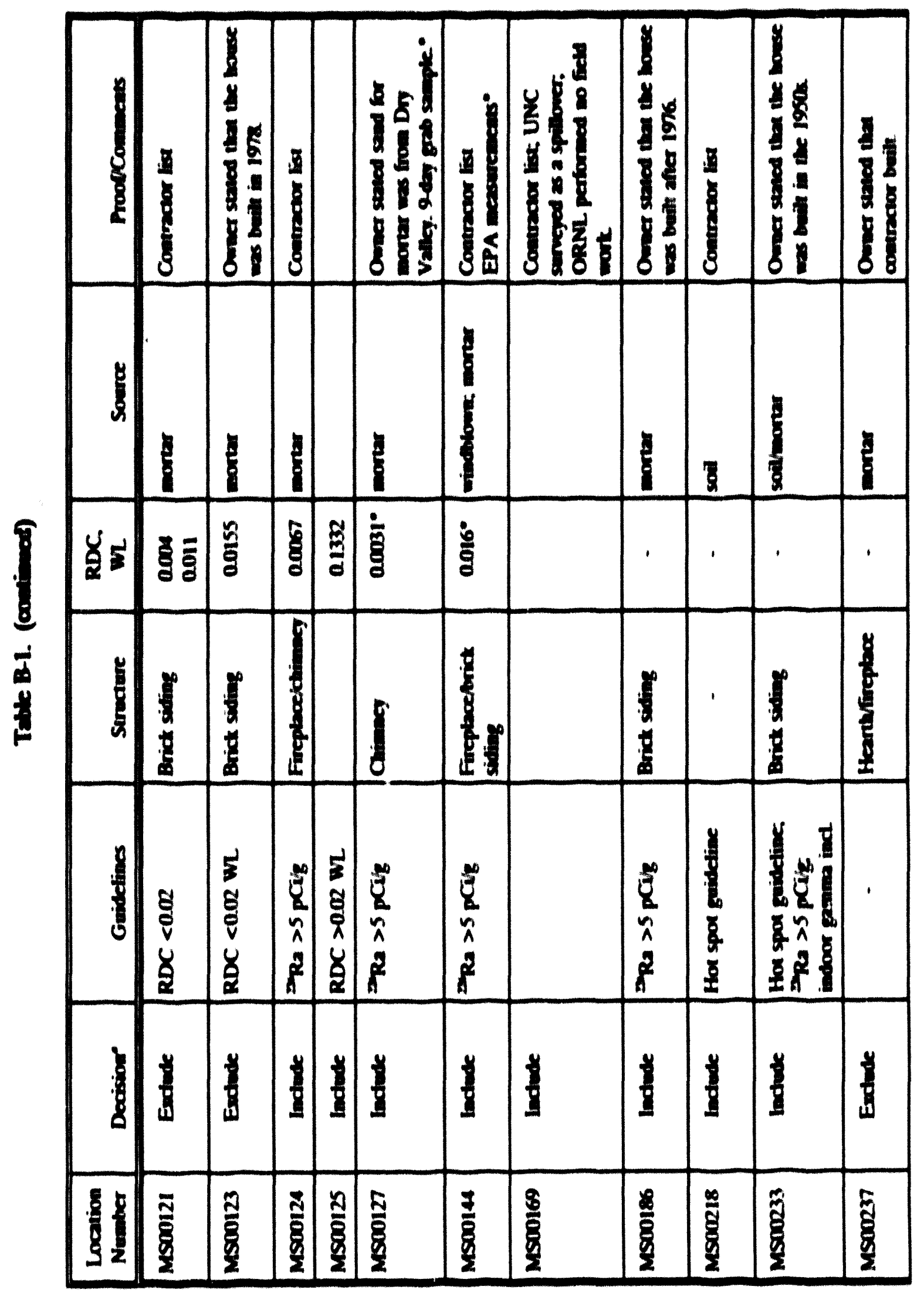


$B-4$

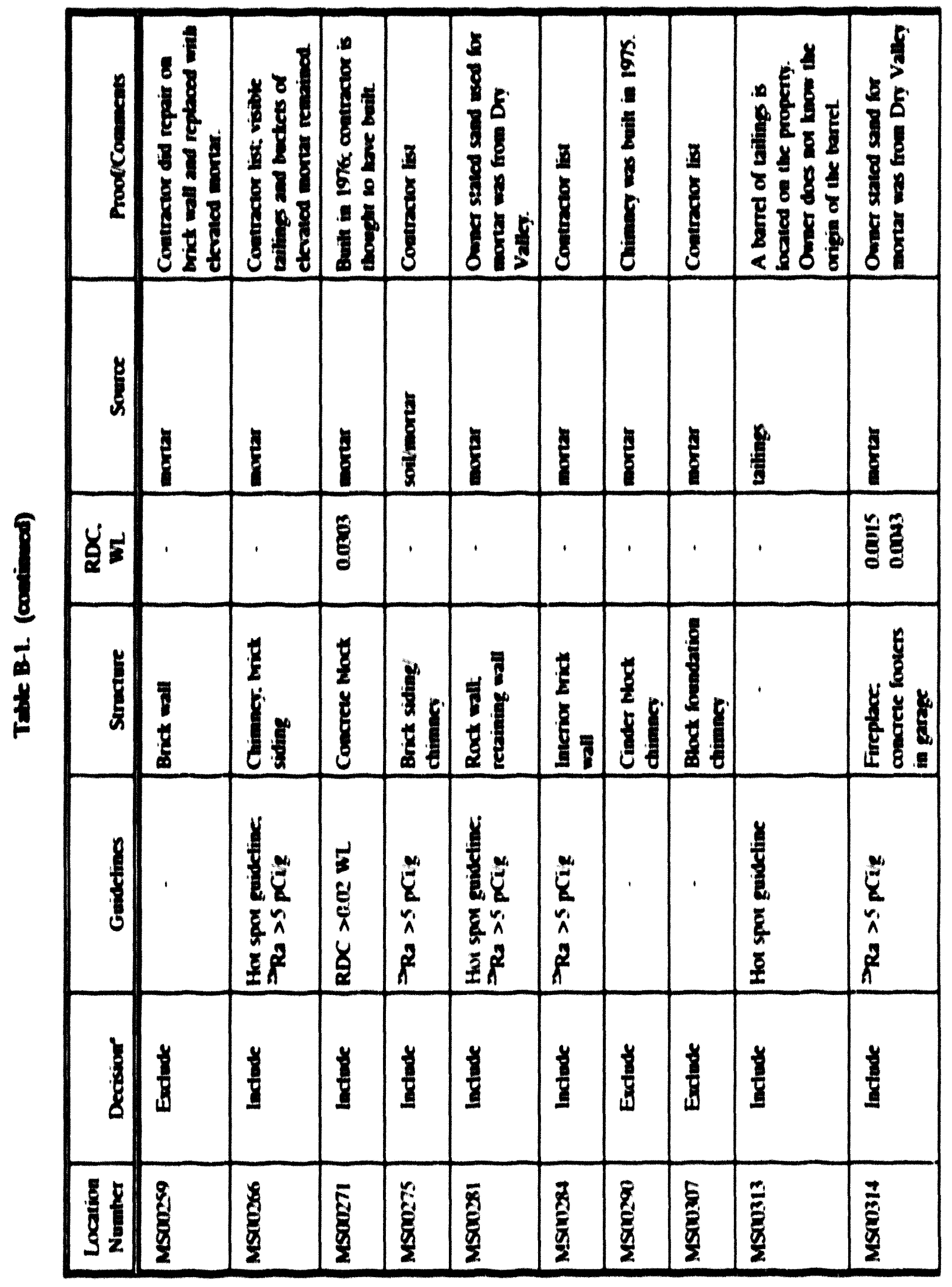




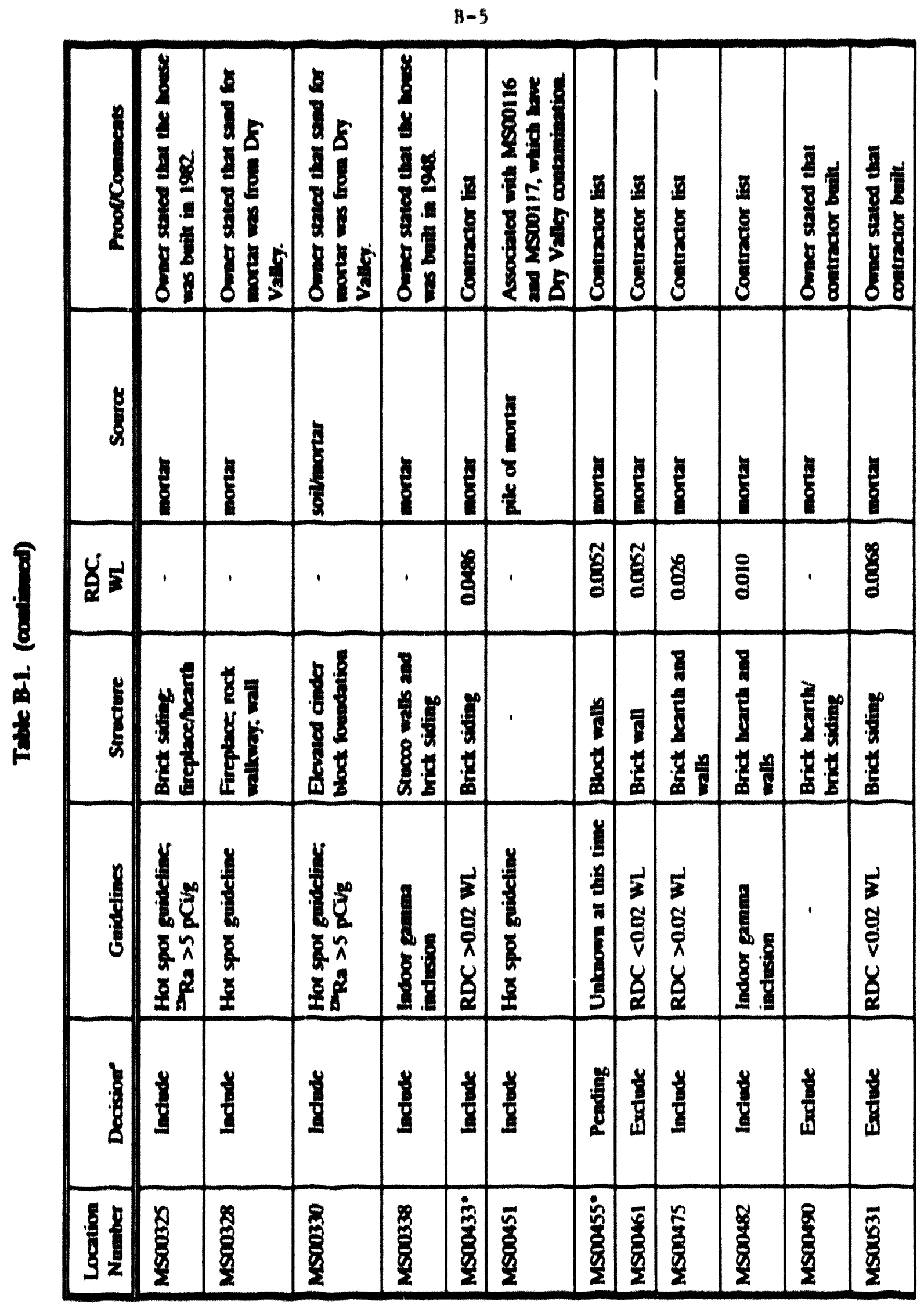


$B-6$

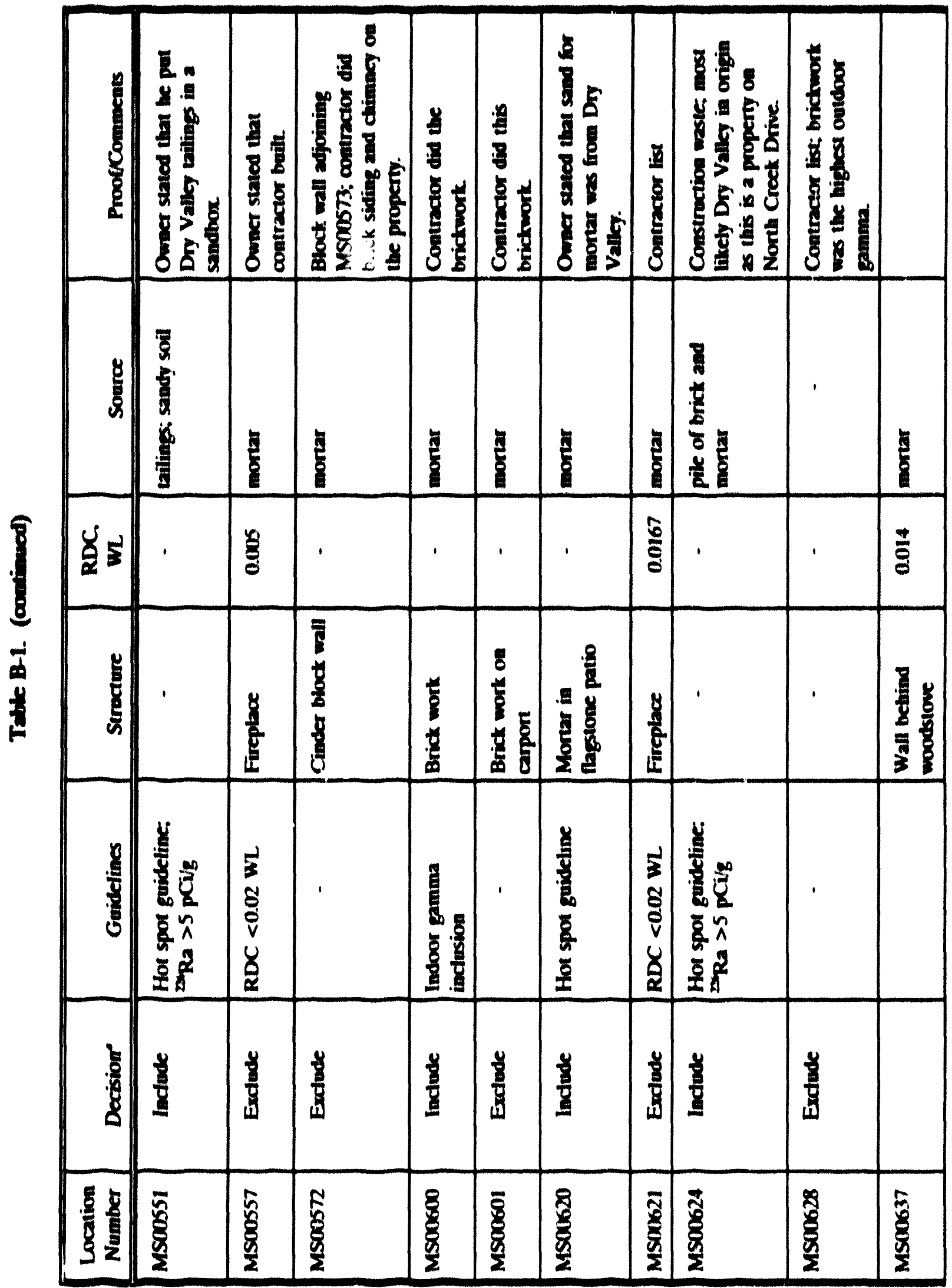


B-7

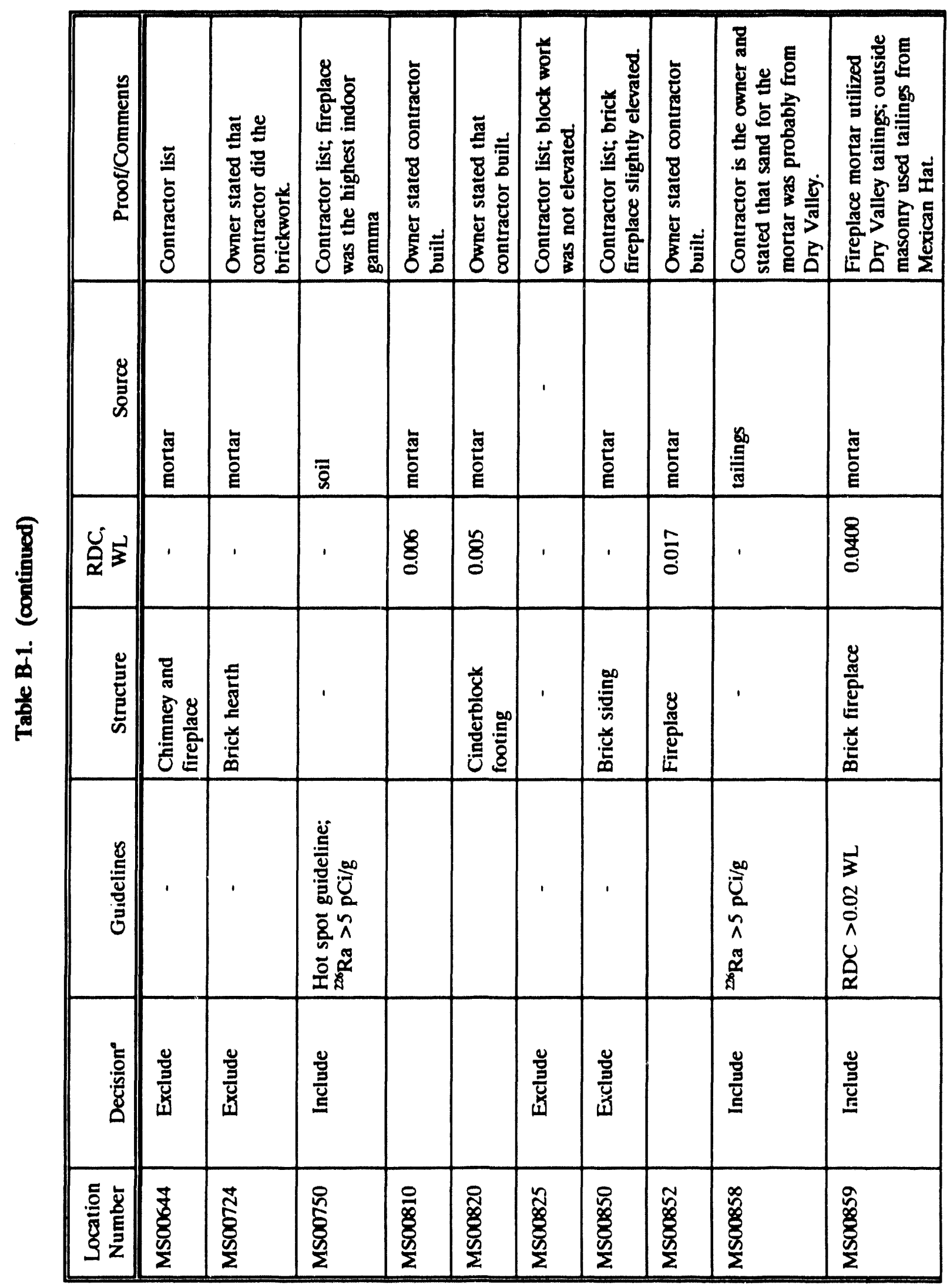




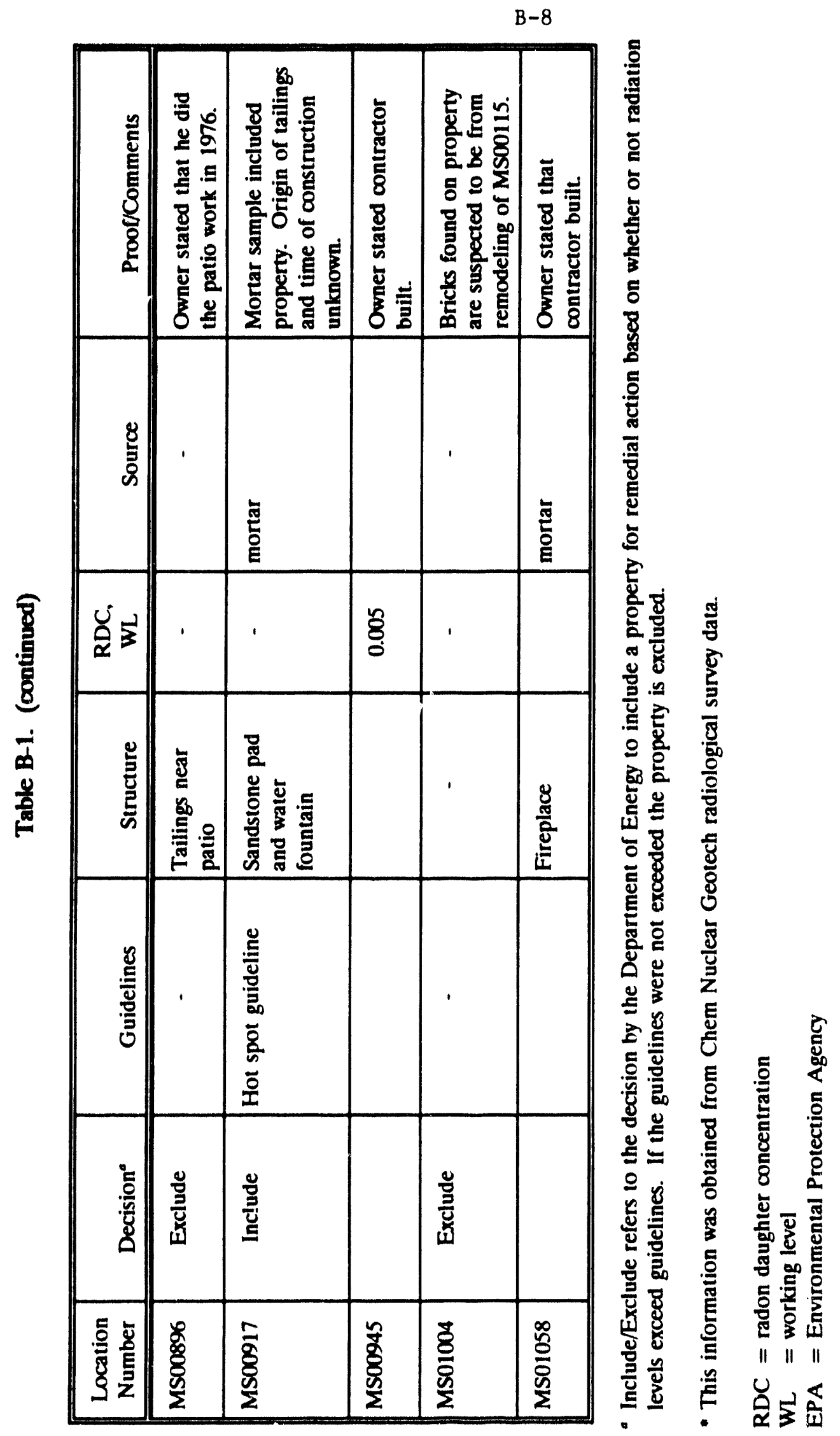




\section{APPENDDX C \\ MISCELLANEOUS AND NATURALLY OCCURRING \\ RADIOACTIVE MATERIAL}




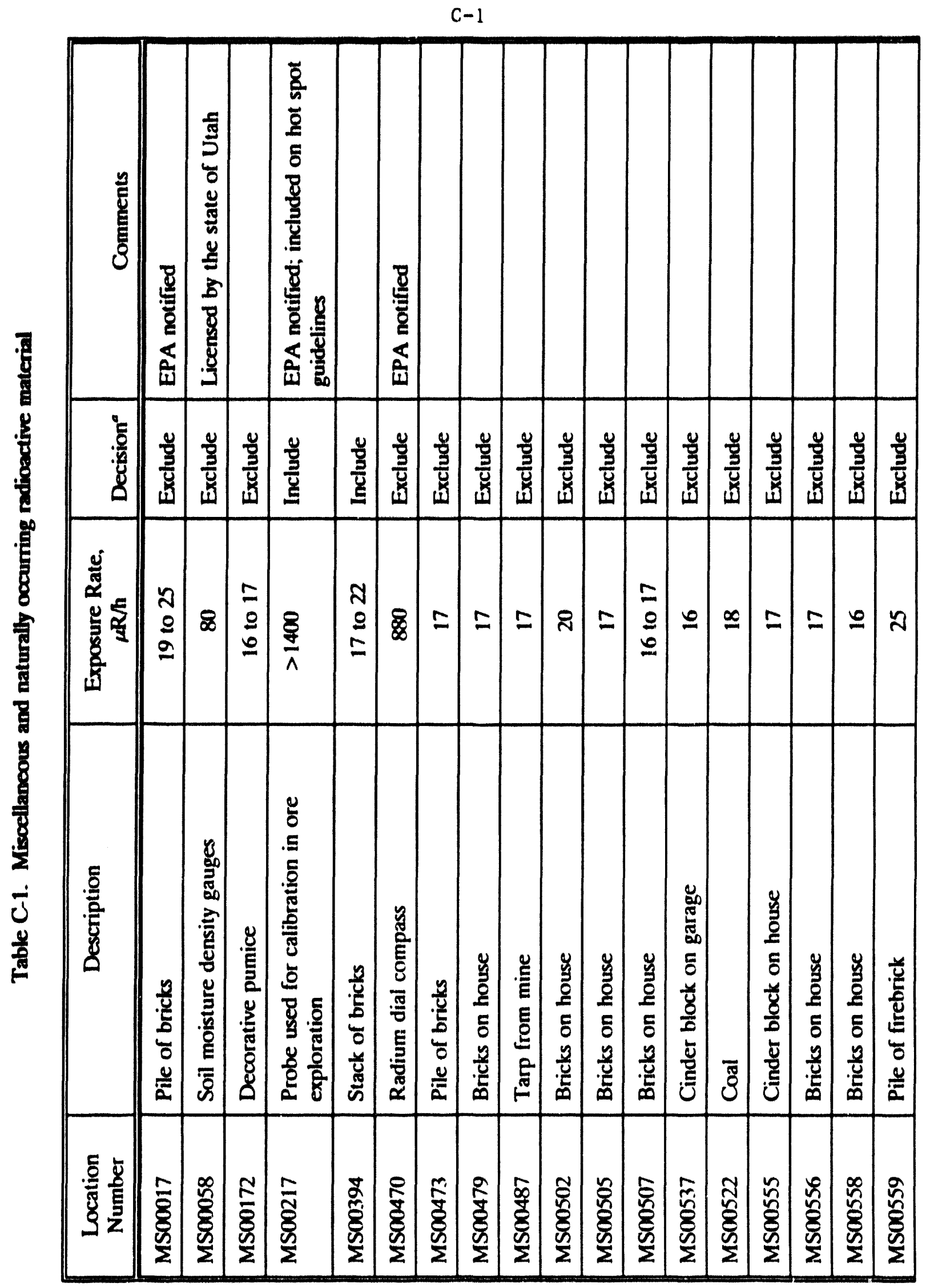




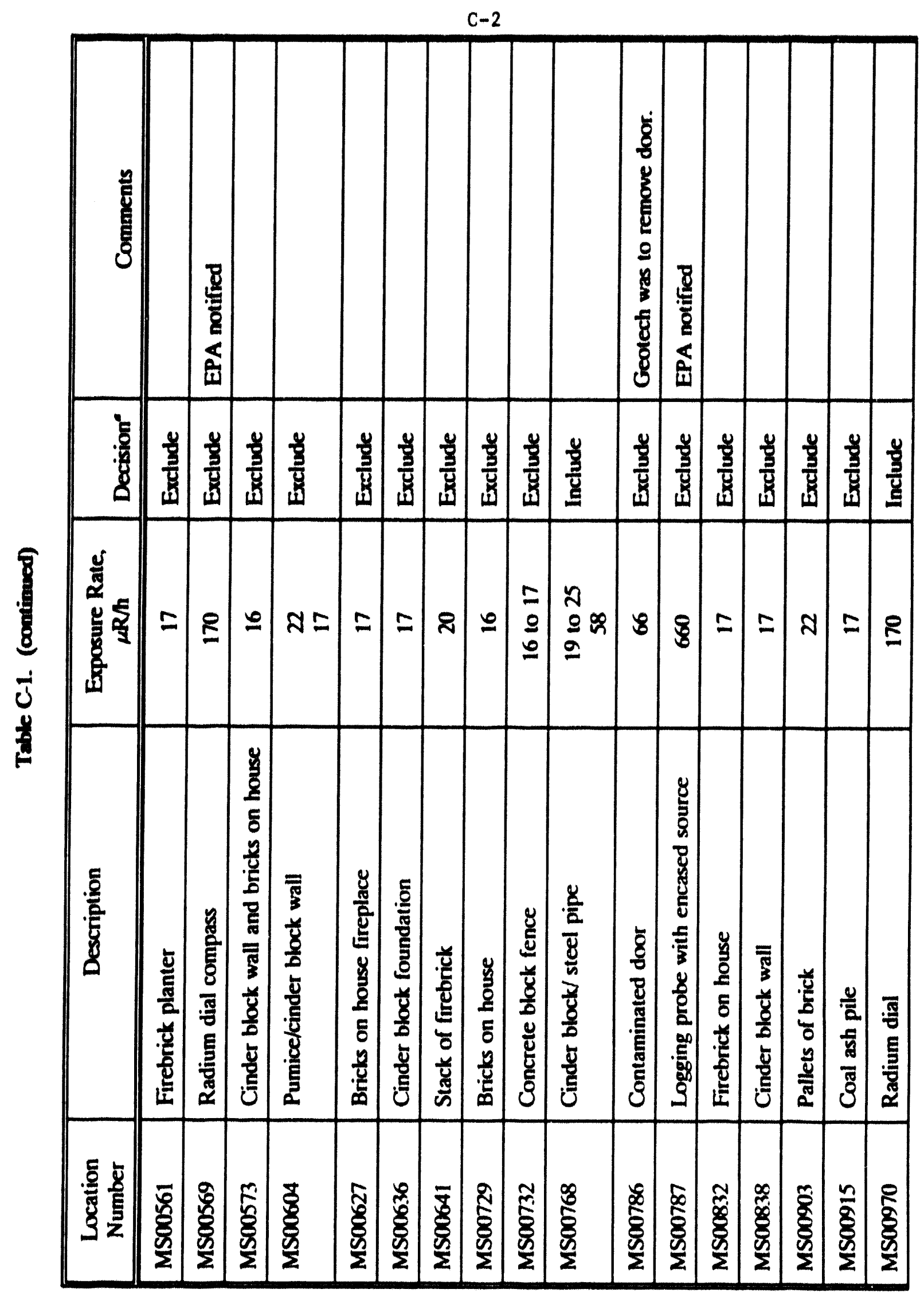




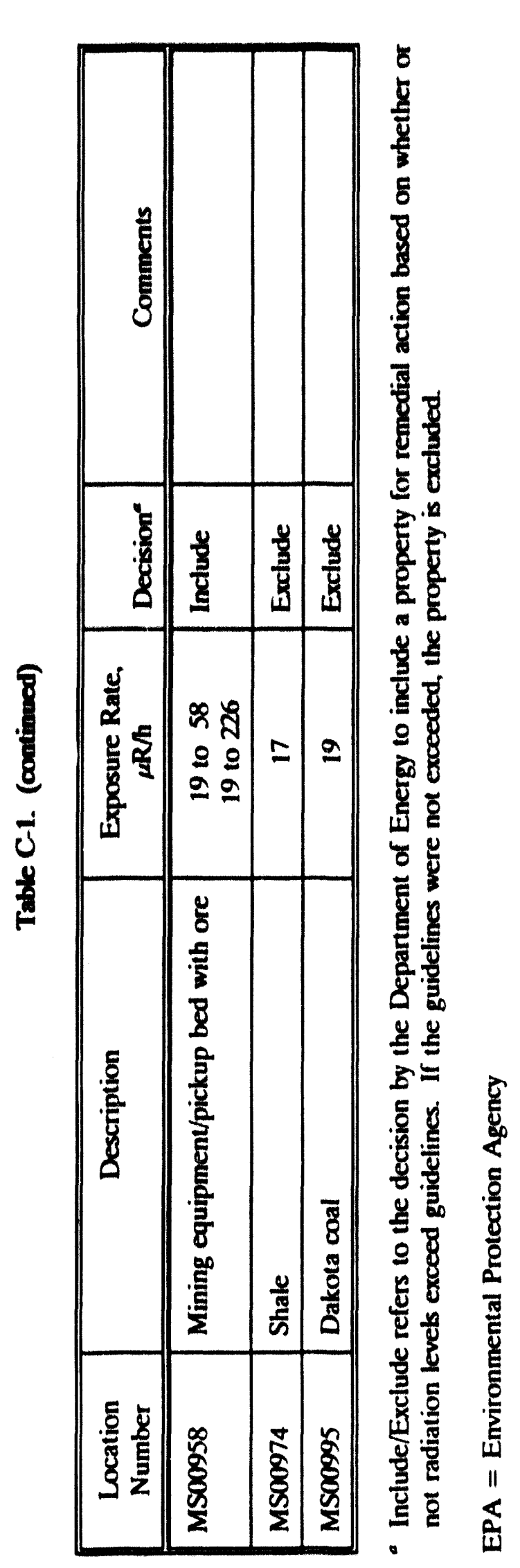


APPENDIX D

COLLECTORS' ITEMS AND OTHER POINT SOURCES 


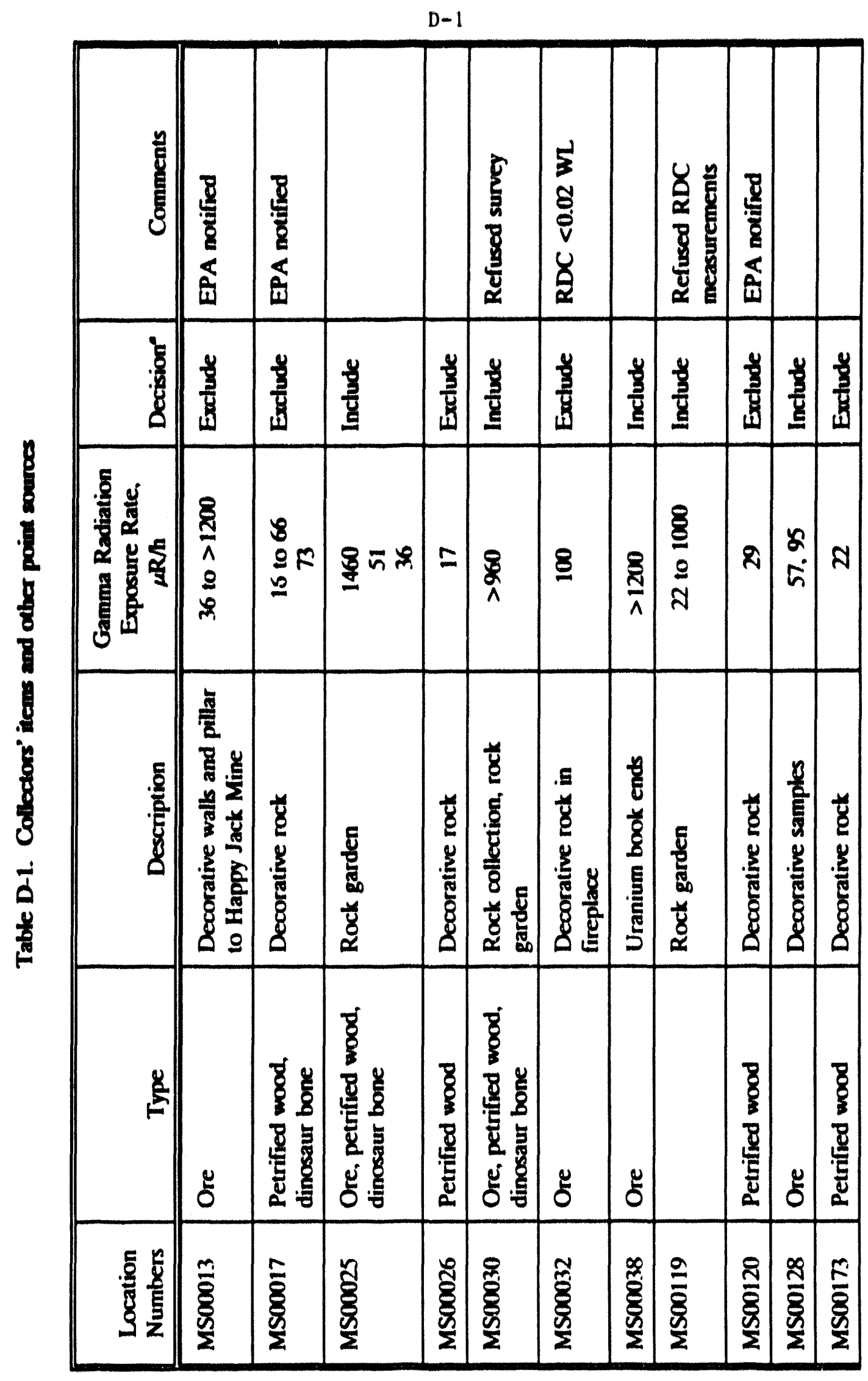




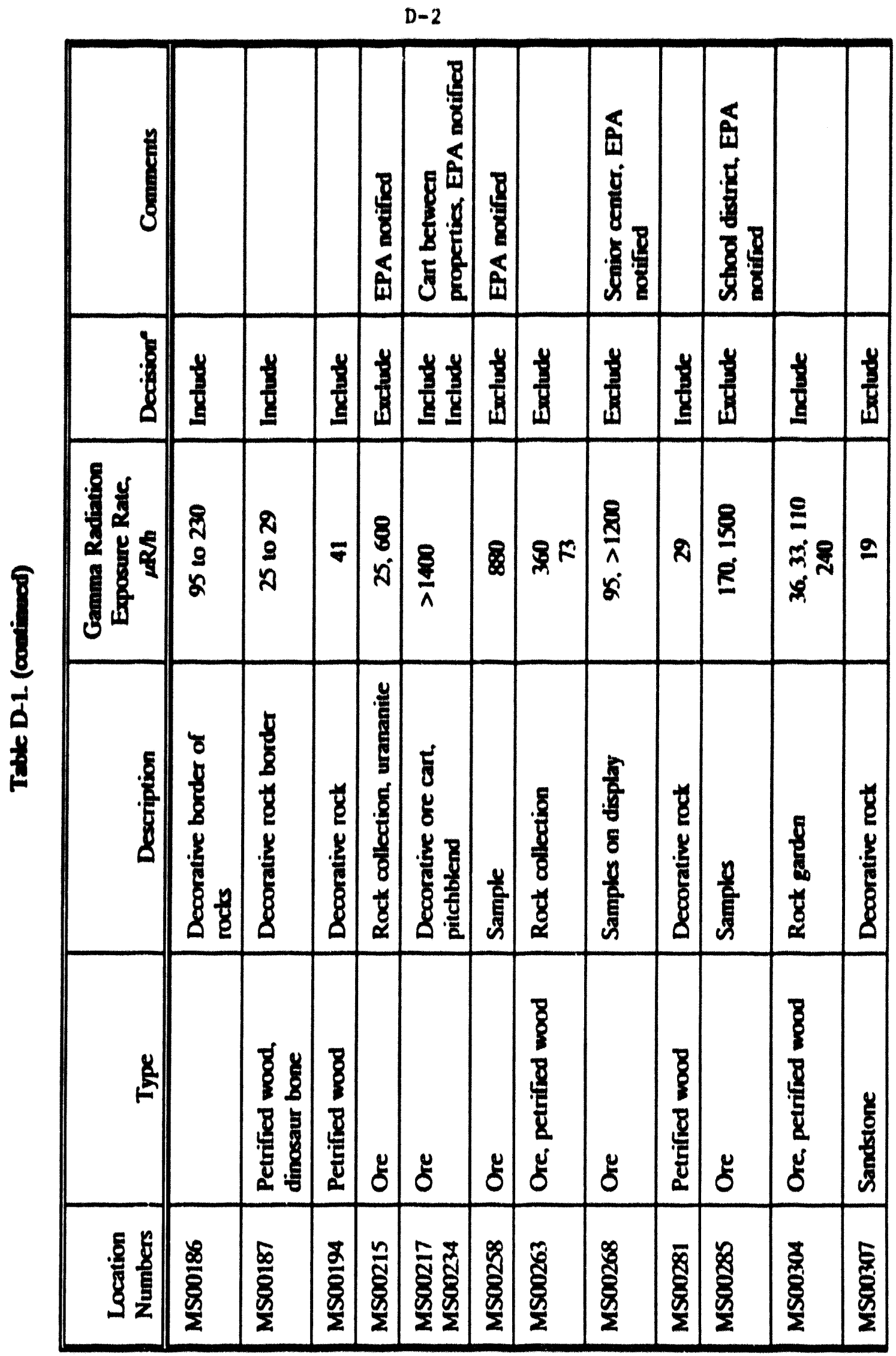




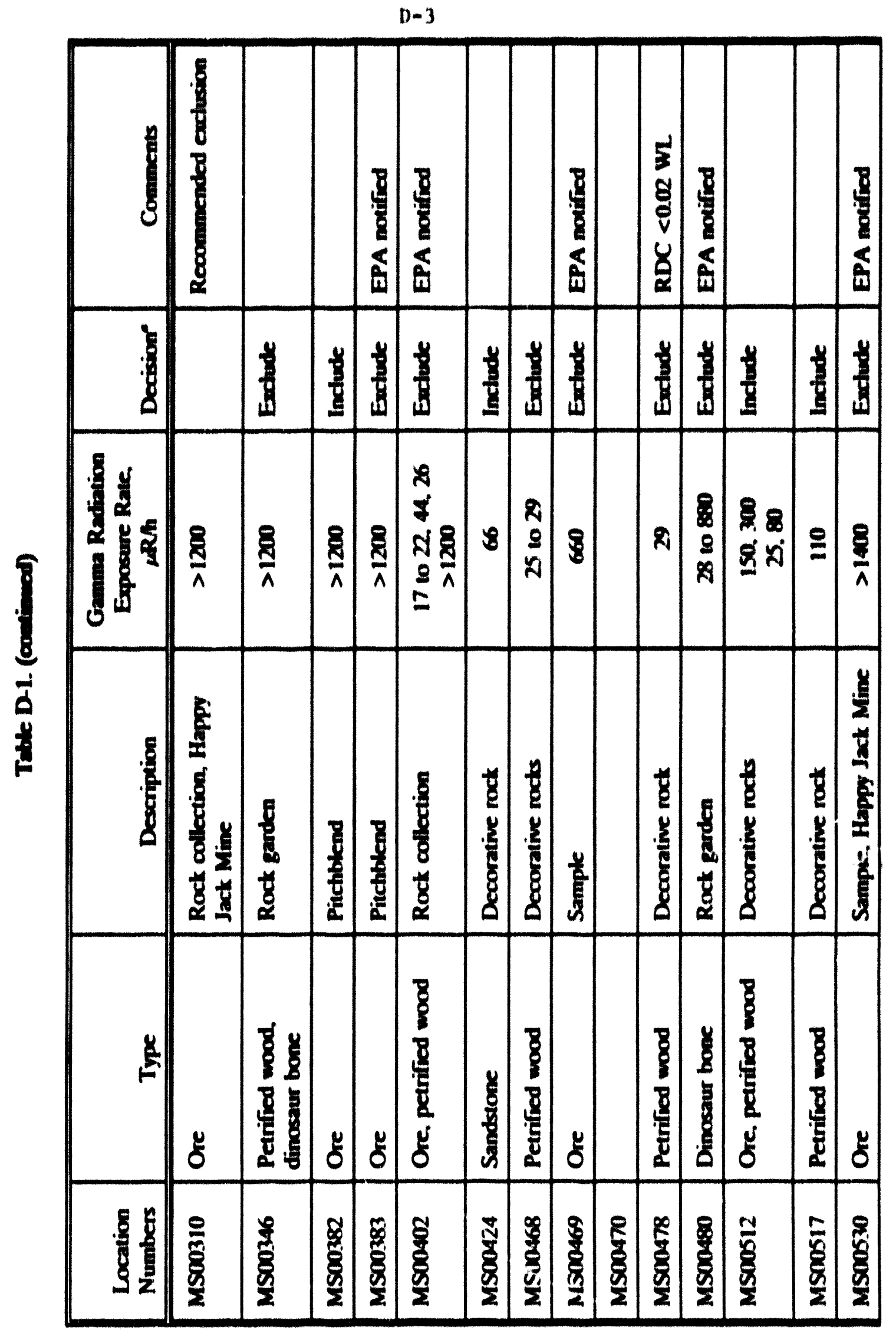




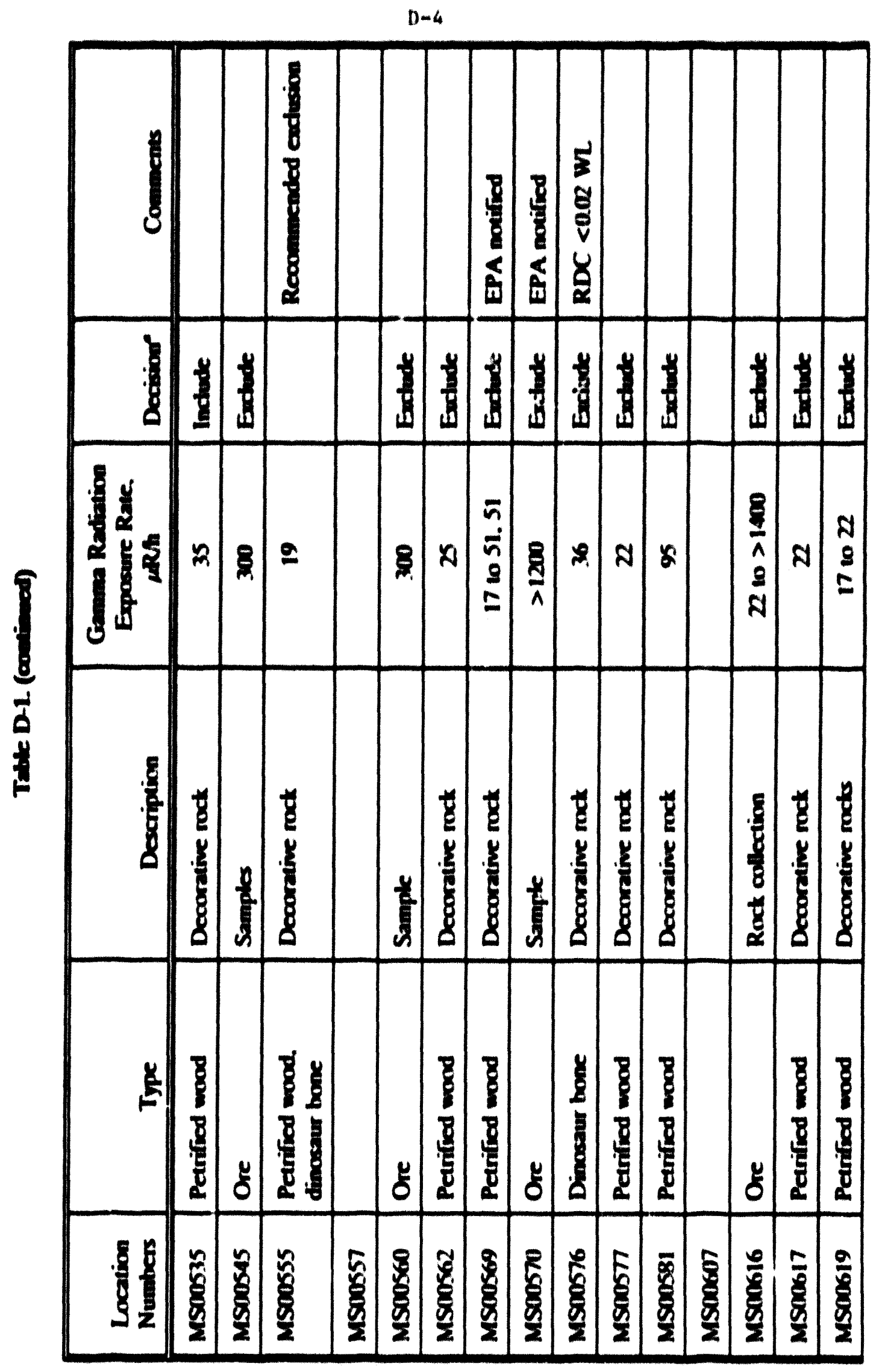




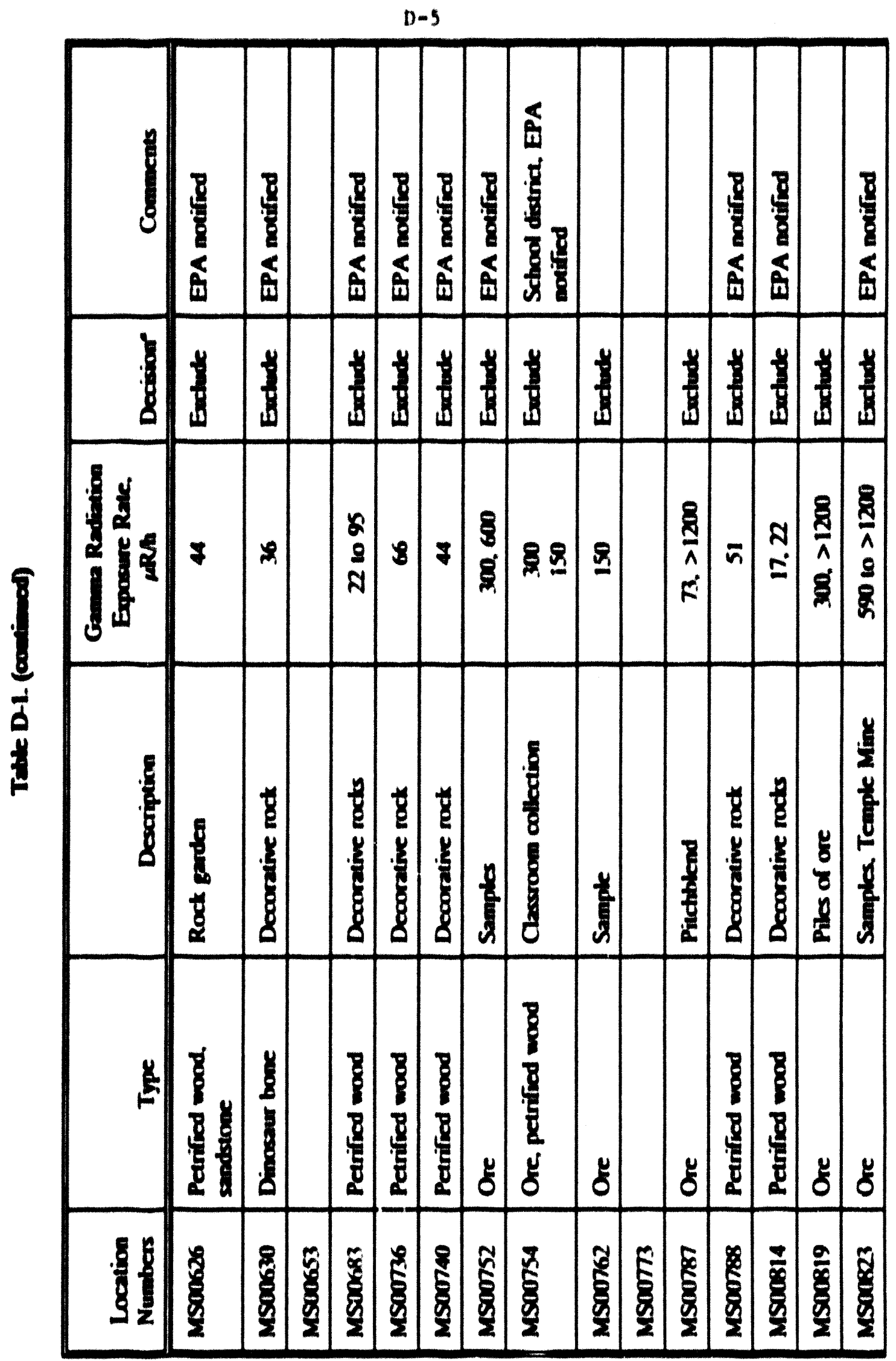




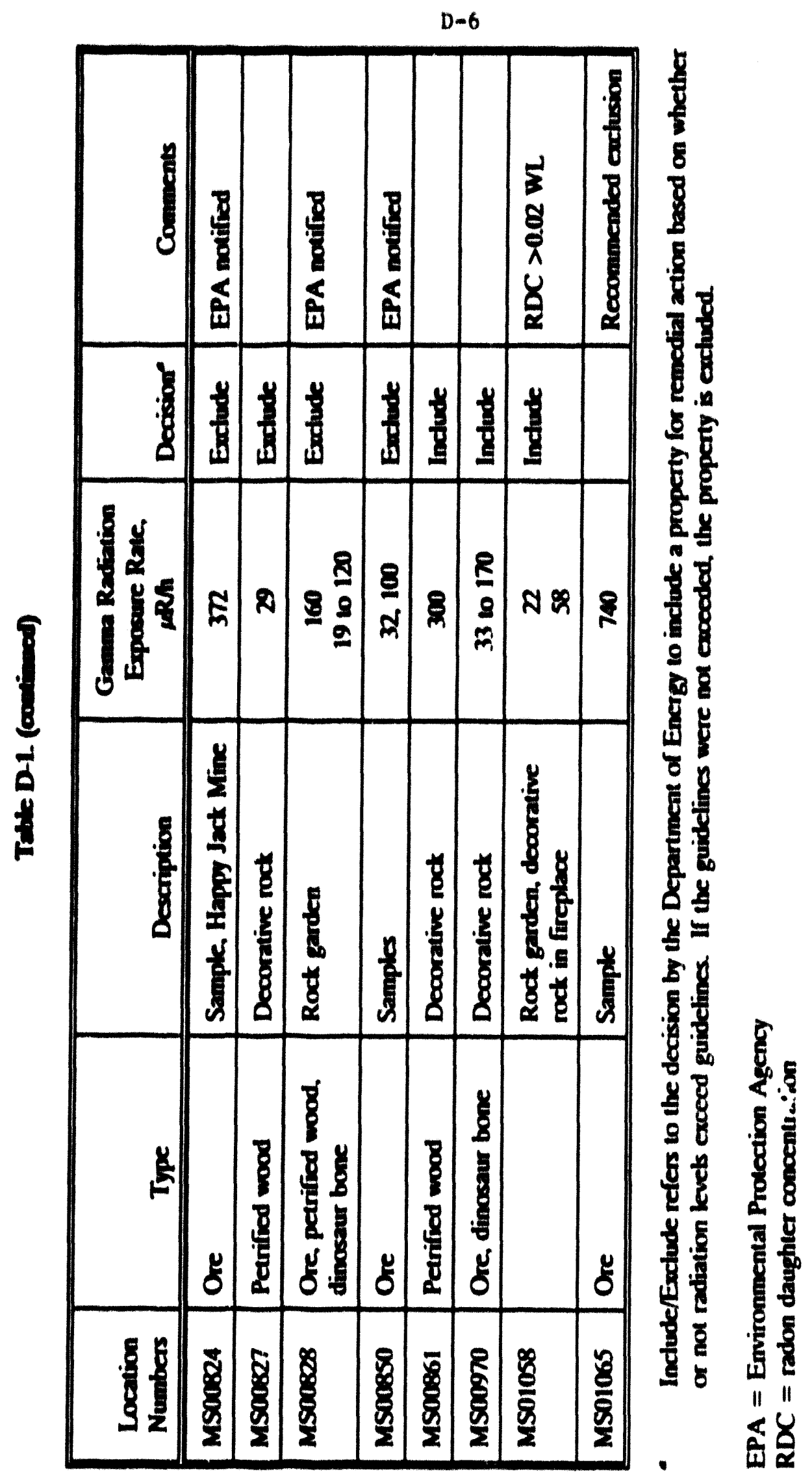


ORNLTM-12368

\section{INTERNAL DISTRIBUTION}
1.
2. J. W. Crutcher
3. D. K. Halford
$4 \cdot 9$.
10.
C. A. Little
11. G. A. Pierce
12. C. D. Retolaza

\author{
13. R. E. Swaja \\ 14. 18. M. J. Wilson \\ 19. Central Research Librury \\ 20 - 21. Laboratory Records \\ 22. Laboratory Records - RC \\ 23. ORNL Patent Section \\ 24. ORNL Technical Library, Y.12
}

\section{EXTERNAL DISTRIBUTION}

25. D. B. Ertel, Oak Ridge Inatitute of Science and Education, P.O. Box 2567, Grand Junction, $\mathrm{CO} 81502$

26 - 27. J. J. Fiore, U.S. Department of Energy, Office of Environmental Reatoration and Waste Management (EM-423), Decontamination and Decummisaioning Division, Washington, DC 20545

28. J. W. Gatrell, U.S. Department of Energy, Office of Environmental Restoration, Southwestern Area Programs Division, Mail Stop EM-451 (OTN), Washington. DC 20545

29. A. R. Jones, Oak Ridge Institute of Science and Education, P.O. Box 2567, Grand Junction, CO 81502

30. R. S. Kowalewski, U.S. Department of Energy, Office of Environmental Restoration, Southwestern Area Programs Division, Mail Stop EM-451 (OTN), Washingion, DC 20545

31. N. F. Lewis, Oak Ridge Institute of Science and Education, P.O. Box 2567, Grand Junction, CO 81502

32. D. S. Lat, Oak Ridge Institute of Science and Education, P.O. Box 2567, Grand Junction, $C O 81502$

33. D. N. Mackenzie, U.S. Department of Energy, Northwest Area Programs Division, D \& D Branch, EM-44, 19901 Germantown Rd., Germantown, MD 20878

34. L. E. Mahier, Booz Allen and Hamilton, 20201 Century Blvd., Gernnantown, MD 20874

35. S. K. Mather, Oak Ridge Institute of Science and Education, P.O. Box 2567, Grand Junction, CO 81502 


\section{EXTERNAL DISTRIBUTION (continued)}

36 - 38. B. W. Mathis, Rust Geotech, P.O. Box 2567, Grand Junction, CO 81502-2567.

39. W. E. Murphie, U.S. Department of Energy, Division of Decommissioning and Decontamination, Eastern Area Programs, Washington, DC 20585

40. M. E. Mumby, Oak Ridge Institute of Science and Education, P.O. Box 2567, Grand Junction, CO 81502

41. H. A. Perry, Rust Geotech, P.O. Box 2567, Grand Junction, CO 81502-2567

42. T. B. Plessinger, U.S. Department of Energy, Grand Junction Projects Office, P.O. Box 2567, Grand Junction, CO 81502

43 - 45. L. K. Price, U.S. Department of Energy, Oak Ridge Operations Office, Technical Services Division, P.O. Box 2001, Oak Ridge, TN 37831-8723

46. E. P. Schlauger, Oak Ridge Institute of Science and Education, P.O. Box 2567, Grand Junction, CO $8150^{\circ}$

47. G. K. Stowe, Oak Ridge Institute of Science and Education, P.O. Box 2567, Grand Junction, CO 81502

48 - 50. M. K. Tucker, U.S. Department of Energy, Grand Junction Projects Office, P.O. Box 2567, Grand Junction, CO 81502-2567

51. W. A. Williams, U.S. Department of Energy, Office of Environmental Restoration and Waste Management (EM-423), Decontamination and Decommissioning Division, Washington, DC 20545

52. Office of Assistant Manager, Energy Research and Development, Oak Ridge Operations Office, P.O. Box 2001, Oak Ridge, TN 37831-8600

53 - 54. Office of Scientific and Technical Information, U.S. Department of Energy, P.O. Box 62, Oak Ridge, TN 37831 

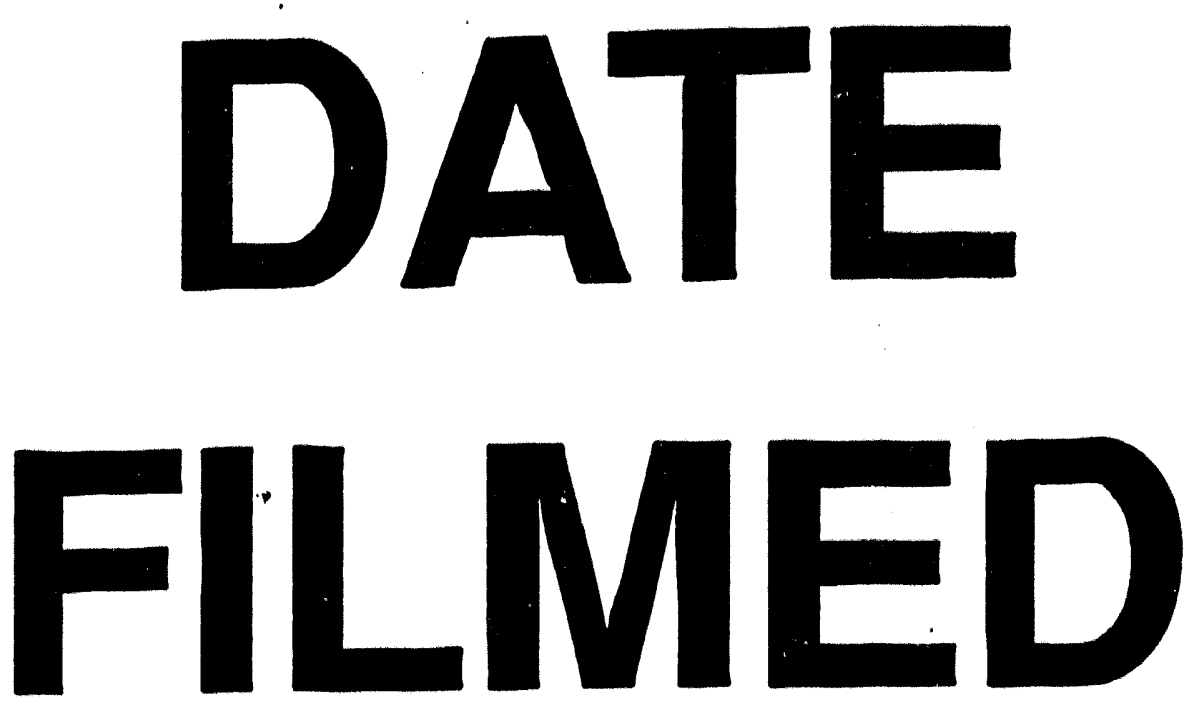

$12 / 6 / 93$
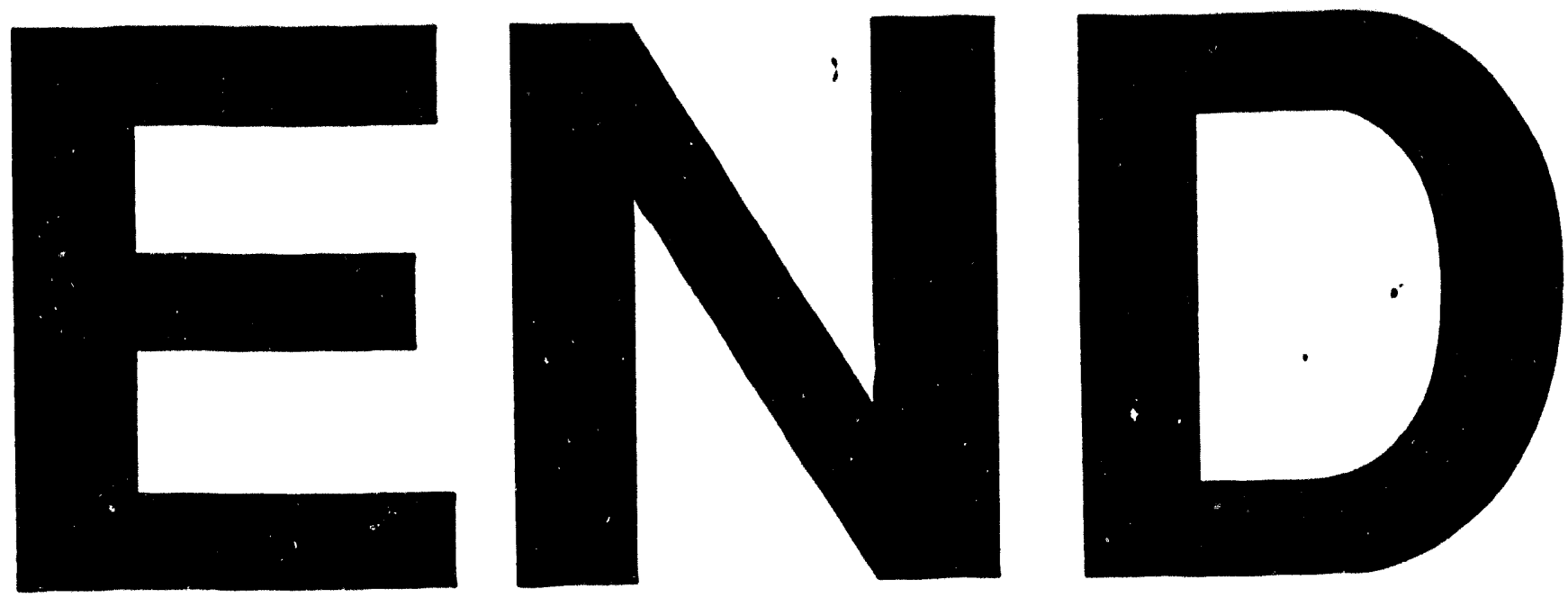


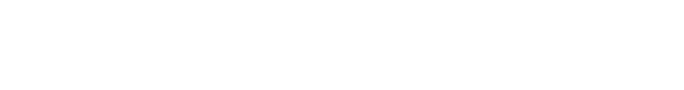

.

$$
\left(\frac{10}{2}\right.
$$

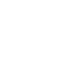
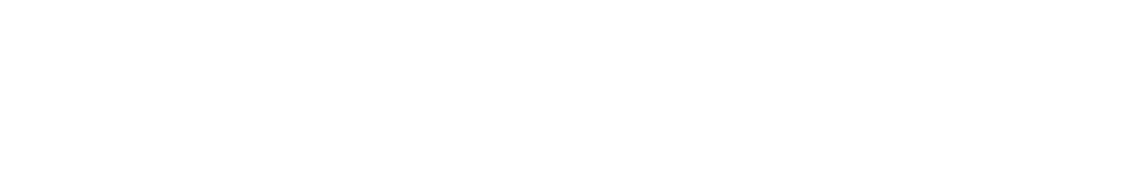